\title{
Short-Term Test Results: Transitional Housing Energy Efficiency Retrofit in the Hot- Humid Climate
}

Karen Sutherland and Eric Martin BA-PIRC/Florida Solar Energy Center

February 2013 


\section{NOTICE}

This report was prepared as an account of work sponsored by an agency of the United States government. Neither the United States government nor any agency thereof, nor any of their employees, subcontractors, or affiliated partners makes any warranty, express or implied, or assumes any legal liability or responsibility for the accuracy, completeness, or usefulness of any information, apparatus, product, or process disclosed, or represents that its use would not infringe privately owned rights. Reference herein to any specific commercial product, process, or service by trade name, trademark, manufacturer, or otherwise does not necessarily constitute or imply its endorsement, recommendation, or favoring by the United States government or any agency thereof. The views and opinions of authors expressed herein do not necessarily state or reflect those of the United States government or any agency thereof.

Available electronically at http://www.osti.gov/bridge

Available for a processing fee to U.S. Department of Energy

and its contractors, in paper, from:

U.S. Department of Energy

Office of Scientific and Technical Information

P.O. Box 62

Oak Ridge, TN 37831-0062

phone: 865.576 .8401

fax: 865.576 .5728

email: mailto:reports@adonis.osti.gov

Available for sale to the public, in paper, from:

U.S. Department of Commerce

National Technical Information Service

5285 Port Royal Road

Springfield, VA 22161

phone: 800.553 .6847

fax: 703.605 .6900

email: orders@ntis.fedworld.gov

online ordering: http://www.ntis.gov/ordering.htm

Printed on paper containing at least $50 \%$ wastepaper, including $20 \%$ postconsumer waste 


\title{
Short-Term Test Results: Transitional Housing Energy Efficiency Retrofit in the Hot-Humid Climate
}

\author{
Prepared for: \\ The National Renewable Energy Laboratory \\ On behalf of the U.S. Department of Energy's Building America Program \\ Office of Energy Efficiency and Renewable Energy \\ 15013 Denver West Parkway \\ Golden, CO 80401 \\ NREL Contract No. DE-AC36-08GO28308 \\ Prepared by: \\ Karen Sutherland and Eric Martin \\ BA-PIRC/Florida Solar Energy Center \\ 1679 Clearlake Road, Cocoa, FL 32922 \\ NREL Technical Monitor: Stacey Rothgeb \\ Prepared under Subcontract No. KNDJ-0-40339-00
}

February 2013 
[This page left blank] 


\section{Contents}

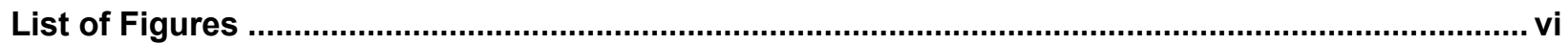

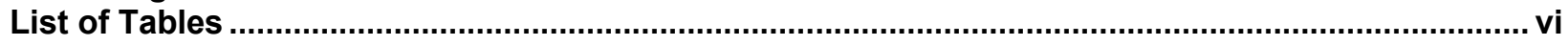

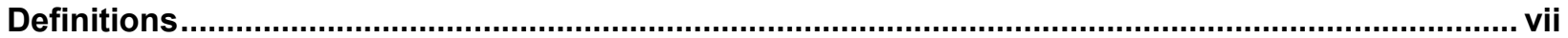

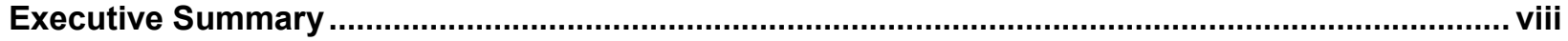

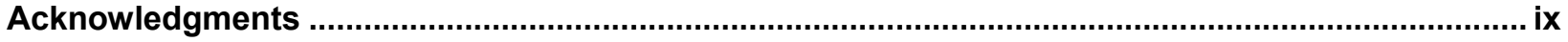

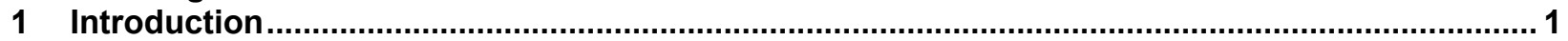

2 Pre-Retrofit Energy Efficiency Characteristics and Retrofit Plans ............................................ 5

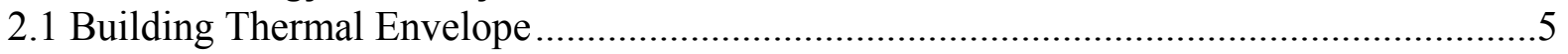

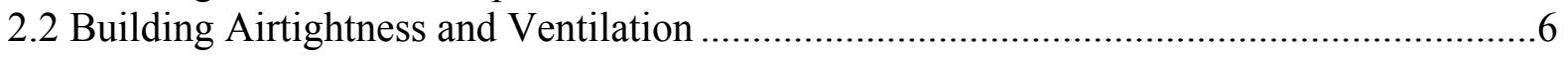

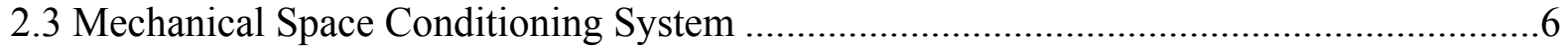

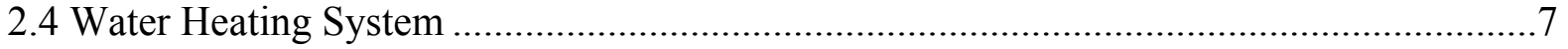

2.5 Lighting, Appliances, and Miscellaneous Loads .................................................... 7

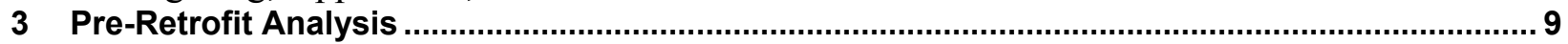

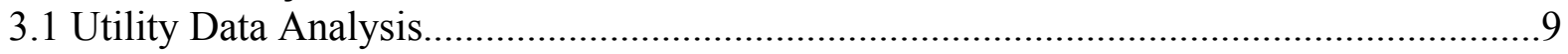

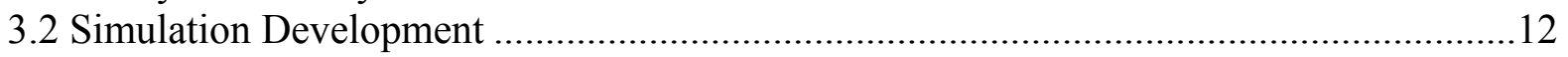

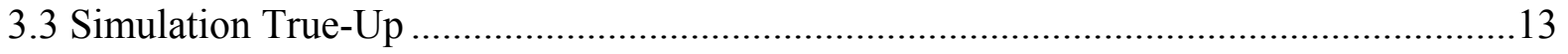

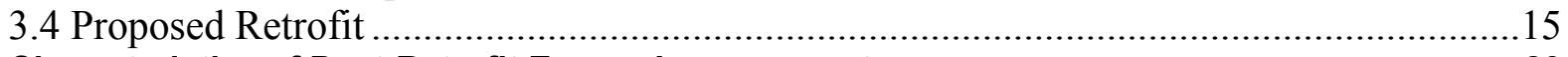

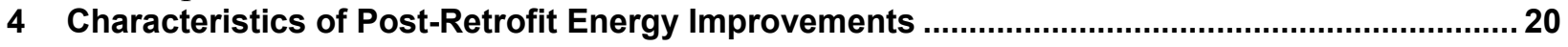

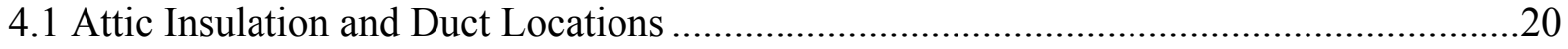

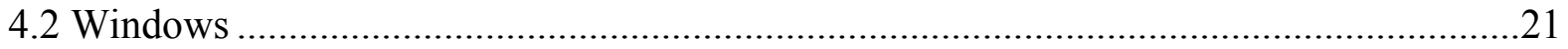

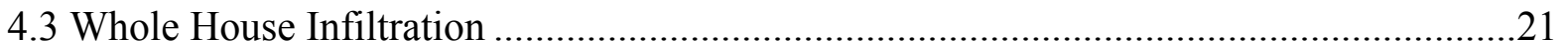

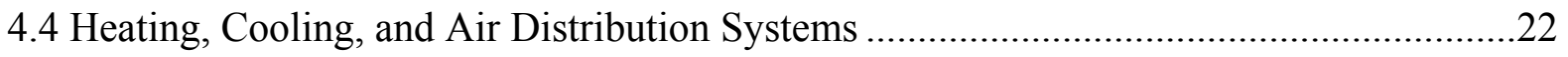

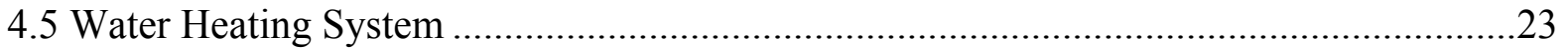

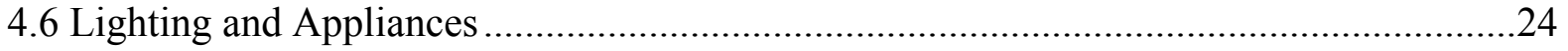

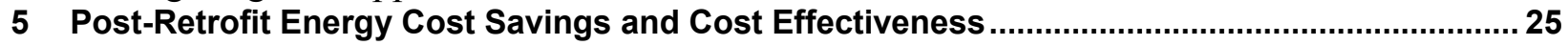

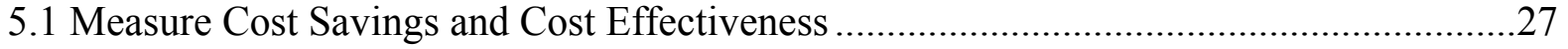

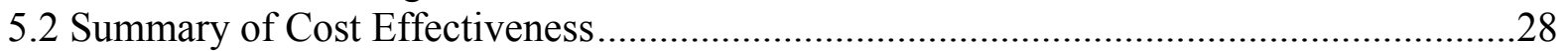

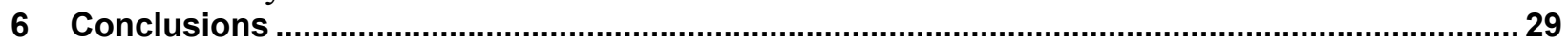

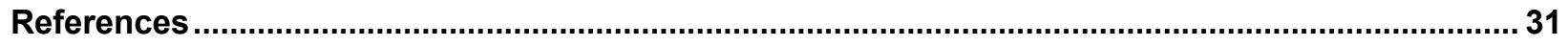

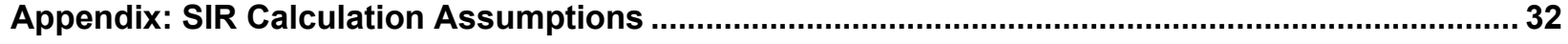




\section{List of Figures}

Figure 1. The Beacon House, transitional men's housing shelter in St. Petersburg, Florida, built in 1926.

Figure 2. Number of existing multifamily housing units in the southern United States, by decade.. 3

Figure 3. Eaves and vented attic of the Beacon House ................................................................. 5

Figure 4. One of two through-the-wall exhaust fans ventilating the kitchen ...................................... 6

Figure 5. Natural gas furnace (left); window AC unit, fitted into rough opening with cardboard and foam (right)

Figure 6. The commercial kitchen (refrigerators, left; range, right) feeds approximately 200 people each night.

Figure 7. Actual and predicted electricity use by CDD. Y-intercept (base load) at 6,551 kWh. ....... 10

Figure 8. Actual and predicted natural use by HDD. Y-intercept (base load) at 65 therms............. 11

Figure 9. Utility costs disaggregated by heating, base therms, cooling, and base $\mathrm{kWh}$.................11

Figure 10. Actual versus TMY3 weather-normalized annual energy costs; changes occur in

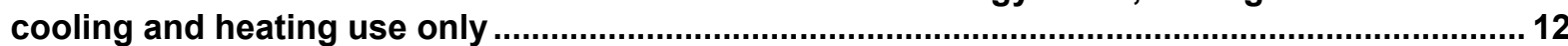

Figure 11. Disaggregated cooling, heating, kWh base load, and therms base load (range) ............ 13

Figure 12. Normalized actual versus simulated monthly energy use. A dip in February simulation therms (purple) results from a warm climate with few HDDs, which is sensitive to localized weather patterns.

Figure 13. Post-retrofit, researchers observed an airflow pathway from a large open wall cavity between the AHU and the filter grille

Figure 14. Post-retrofit ground floor, SEER 15 heat pump AHU ................................................. 22

Figure 15. Two externally mounted gas tankless water heaters..................................................... 24

Unless otherwise indicated, all figures were created by the BA-PIRC team.

\section{List of Tables}

Table 1. Sample Utility Billing Periods Used to Estimate Monthly Consumption .............................. 9

Table 2. Proposed Retrofit Package and Predicted Annual Energy Cost Savings ${ }^{\mathrm{a}}$.......................... 16

Table 3. Post-Retrofit Findings by Measure ${ }^{a}$

Table 4. Post-Retrofit Measure and Package Costs and Savings ${ }^{a}$

Unless otherwise indicated, all tables were created by the BA-PIRC team. 


\section{Definitions}

AFUE Annual fuel utilization efficiency

AC Air conditioning

ACH50 Air changes per hour when a house is depressurized to negative 50 Pascals

AHU Air handling unit

BA-PIRC Building America Industrialized Housing Partnership

CDD Cooling degree days

CFL Compact fluorescent lamp

CFM Cubic feet per minute

DOE-2 An energy use perdition software developed by James J. Hirsch \& Associates in collaboration with Lawrence Berkeley National Laboratory

EER Energy efficiency ratio

EF Efficiency factor

EGUSA Energy Gauge USA

HDD Heating degree days

HSPF Heating seasonal performance factor

$\mathrm{kWh} \quad$ Kilowatt hour

$\mathrm{Pa} \quad$ Pascal

R-value Value denoting thermal resistance

RESNET Residential Energy Services Network

SEER Seasonal energy efficiency ratio

SHGC Solar heat gain coefficient

SIR Savings to investment ratio

TMY3 Typical Meteorological Year 3

Qn,out Normalized duct system leakage to the outside; a measurement of duct leakage to non-conditioned space at test pressure of negative 25

Pascals divided by the conditioned floor area

$\mathrm{R}^{2} \quad \mathrm{R}$-squared, coefficient of determination

U-value Value denoting thermal conductance 


\section{Executive Summary}

This project evaluates the renovation of a 5,800- $\mathrm{ft}^{2}$, multiuse facility located in St. Petersburg, on the west coast of central Florida, in the hot-humid climate. An optimal package of retrofit measures was designed to deliver 30\%-40\% annual energy cost savings for this building with annual utility bills exceeding $\$ 16,000$ and high base load consumption. Researchers projected energy cost savings for potential retrofit measures based on pre-retrofit findings and disaggregated, weather-normalized utility data. A cost-benefit analysis was conducted for the seven retrofit measures implemented; adding attic insulation and sealing soffits, tinting windows, improving whole-building airtightness, upgrading heating and cooling systems and retrofitting the air distribution system, replacing water heating systems, retrofitting lighting, and replacing laundry equipment.

Based on additional data collected from a post-retrofit audit, the projected energy cost savings for the full retrofit package are 35\%; projected annual energy cost savings are $\$ 5,375$.

Projections using full measure costs indicate that the lighting retrofit and window film measures yield the highest savings to investment ratios. However, when considering only incremental costs, the high-efficiency heating and air conditioning systems presented the strongest savings to investment ratio.

The building's architectural characteristics, vintage, and occupancy profile presented challenges from a simulation perspective and from an audit/data collection perspective to optimize a retrofit measure package and resulting economic projection. This report addresses these challenges in an effort to assist contractors and energy auditors implementing deep-energy retrofits in structures with characteristics that are similar to the subject building. The report also includes a true-up methodology that aligns pre-retrofit utility data with simulation weather data, a technique that is useful for modeling energy efficiency retrofits in general. 


\section{Acknowledgments}

The authors gratefully acknowledge the U.S. Department of Energy, Office of Energy Efficiency and Renewable Energy, which sponsored this work under the Building America Program.

The authors wish to thank Ken Fonorow, the certified home energy rater who conducted the energy audits. We also appreciate the cooperation and support of our industry partner in this work, Sam Moore with Matrix Construction, without whom this research would not have been conducted. We are also grateful to the staff and residents of the Free Clinic Beacon House, specifically Yolanda Giovannetti, and its parent organization, the St. Petersburg Free Clinic, Inc., for providing the research building and for their cooperation and input.

We also express great appreciation to the Florida Solar Energy Center's Danny Parker, who provided energy modeling consultation, Janet McIlvaine who gave technical guidance, and Danielle Daniel for her excellent editorial assistance. 


\section{Introduction}

Free Clinic Beacon House, hereafter referred to as the Beacon House (see Figure 1), is owned and operated by St. Petersburg Free Clinic, Inc., ${ }^{1}$ a multiuse facility that provides transitional shelter to homeless men. The shelter can sleep and feed up to 30 men and provides community evening meals for approximately 200 people every day. The facility also provides its residents with bathing, laundry, and dining accommodations. A large commercial kitchen allows for food storage and preparation for the community meal services.

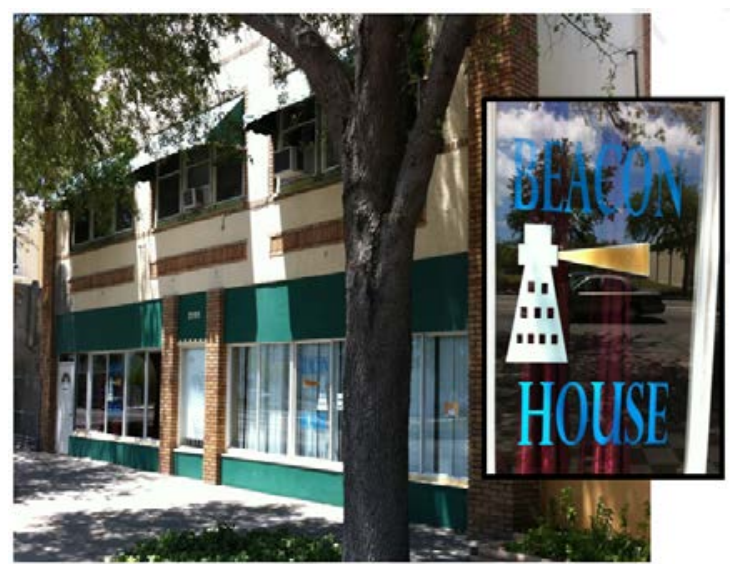

Figure 1. The Beacon House, transitional men's housing shelter in St. Petersburg, Florida, built in 1926

Constructed in 1926, the concrete block, two-story building comprises approximately 5,800 $\mathrm{ft}^{2}$ of conditioned and semiconditioned space with a flat, vented, gravel roof. The building's kitchen is not conditioned or isolated from the rest of the building with an air/thermal barrier. The first floor houses an office, two bathrooms, a dining area, a serving area, a kitchen, a general assembly area, and a laundry room. The second floor consists of two offices, four semiprivate rooms, a large dormitory with 28 bunk beds, and two bathroom areas containing several sinks, toilets, and showers.

The unique characteristics of the home include high occupancy with respect to living area (occupant density), frequent movement of residents and staff in and out of the building, dissimilar resident sleep patterns (approximately 25\% of their residents work an evening or a night shift), three commercial offices shared by three full-time and two part-time staff members, and a commercial kitchen operating throughout most of the day. The clinic administration targets residents who will have minimum six-month tenures; occasionally, however, emergency referrals are taken in from local shelters.

Reported annual utility costs for the mixed-fuel building exceed $\$ 16,000$ (approximately $\$ 14,000$ for electricity and $\$ 2,000$ for natural gas). The natural gas fuels two space heating furnaces and a commercial range.

\footnotetext{
${ }^{1} \mathrm{http}: / /$ www.stpetersburgfreeclinic.org/
} 
Driven to reduce operational costs, the Beacon House sought grant funding to renovate the building. In addition to being expensive to run, the staff described building temperature and humidity as difficult to control. Funding to retrofit the building came from HomeAid, ${ }^{2}$ a nonprofit organization that has partnered with the Walmart Foundation to create an Environmental Sustainability Program that is designed to integrate environmental sustainability into shelter development. Its target metrics are to reduce total annual utility costs by $40 \%$ and recover retrofit costs within five years. The Beacon House staff members are excited about reducing their energy use, as any operational cost savings will be directed toward such things as medical treatment, transportation, and job interviewing skills development for the population served by its umbrella organization, the St. Petersburg Free Clinic.

The St. Petersburg Free Clinic contracted with Matrix Construction, Inc., hereafter referred to as Matrix, as general contractor for the Beacon House retrofit. Technical assistance in designing a retrofit package aimed at meeting the goals of Beacon House and the funding program's target metrics was provided by the Building America Partnership for Improved Residential Construction (BA-PIRC), which predicted savings and calculated paybacks for various energy conservation strategies.

Building performance modeling based on a low-level pre-retrofit energy audit was conducted with Energy Gauge USA (EGUSA) (Florida Solar Energy Center 1996-2005), a DOE-2 based hourly home energy use simulation software program. Thermal envelope measurements and characteristics, and equipment features and locations were documented during the audit for the simulation input. A model based on the pre-retrofit audit was used in conjunction with actual utility data to construct a baseline simulation model from which to run parametric analyses to predict energy cost savings for different features and components.

To secure funding for the retrofit, an initial cost-benefit analysis was conducted for each proposed measure and for the proposed retrofit package as a whole to present to the funding agency. Matrix provided retrofit cost estimates based on subcontractor bids. For each proposed measure and for the retrofit package as a whole, projected annual energy cost savings were divided by associated retrofit costs to estimate simple payback, a metric established by the funding organization.

A post-retrofit energy audit was conducted, including blower door and duct blaster tests to measure whole-building and mechanical distribution system leakage. A revised energy use simulation based on the post-retrofit audit was compared to the pre-retrofit baseline model to predict energy cost savings for completed measures and the overall retrofit package. Post-retrofit interviews with Matrix and the Beacon House administration provided insights into the renovation process from contractor and occupant perspectives.

Actual contractor costs were not available as of December 2012; thus, original subcontractor bids were used as input for post-retrofit cost-effectiveness analyses. In addition to calculating the simple payback according to the funding organization's metrics, researchers calculated savings to investment ratio (SIR). In follow-up to the retrofit, the Beacon House will provide HomeAid copies of its utility data for 12 months following the renovation.

\footnotetext{
${ }^{2} \mathrm{http}: / /$ www.homeaid.org/About-Us
} 
Findings from this research may have broader applicability to multifamily retrofits of similar vintage. Multifamily building census data for the southern United States are referenced as an approximation for dwellings in the hot-humid climate. Figure 2 plots housing units by decade and shows that older vintage housing structures with 5 to 49 units abound in the southern region. As of the 2000 U.S. Census (Residential Finance Survey 2001: Census 2000 Special Reports 2005), approximately 25 million multifamily housing properties with 5 to 49 units were built before 1960 in the southern region of the United States.

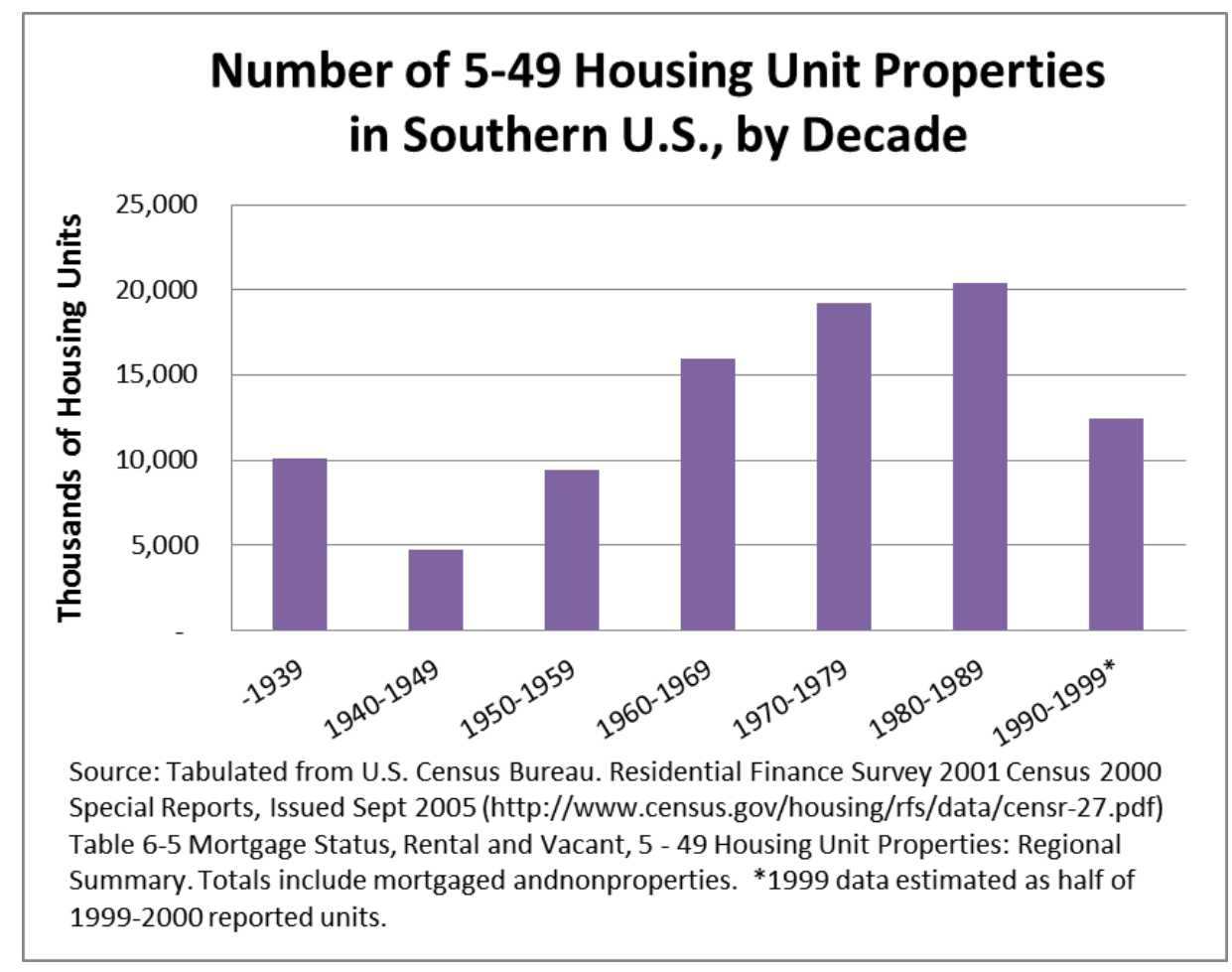

Figure 2. Number of existing multifamily housing units in the southern United States, by decade

This study has more specific relevance to retrofits of shared-use facilities such as transitional housing, dormitories, and assisted living facilities, which are partially commercial given the services provided. According to the U.S. Census Bureau, there were 3,434 temporary shelters nationwide, as of 2002 (Industry Statistics Sampler: NAICS 624221 Temporary Shelters 2002). Among these, 635 structures are located in southern states in the hot-humid climate region: Texas, Florida, Georgia, South Carolina, Alabama, Louisiana, and Mississippi. Transitional shelters conducting high performance retrofits not only improve occupant comfort and structure durability. By reducing building operating costs, the providers benefit from lower monthly electricity and natural gas expenses, thereby freeing funds to enhance delivery services.

Energy conservation measures that focus on cost-effective approaches for multifamily housing retrofits are well documented (Brozyna 2012, for example); however, research specific to the unique attributes of shared-use facilities is scarce in the literature. This report answers the following questions in an effort to help contractors and energy auditors overcome the challenges of implementing deep-energy retrofits in structures with similar characteristics to the subject building. 
- What potential obstacles are presented in evaluating energy use in a building with these architectural and operational characteristics?

- What possible difficulties are presented in retrofitting a transitional housing building with these architectural characteristics and of this vintage?

- What measures may provide the best projected energy cost savings and SIRs in a facility with similar characteristics and services? 


\section{Pre-Retrofit Energy Efficiency Characteristics and Retrofit Plans}

In September 2011, researchers conducted a low-level energy audit of the Beacon House. Following is a summary of the building's components, highlighting energy efficiency parameters used in simulation modeling.

\subsection{Building Thermal Envelope}

Medium-colored tar and gravel covered the decking of the building's built-up flat roof, which had an estimated surface solar absorptance of 0.75 . The vented attic with $2-\mathrm{ft}$ eaves is presented in Figure 3. The attic depth and insulation value could not be visually inspected during the preretrofit energy audit because the attic was not accessible, and the scope of the low-level energy audit did not permit destructive investigation. It may have been possible to use a small scope or viewer, but the level of insulation was expected to be so variable that ascertaining an average would have been difficult. The location of the internal attic hatch was in a precarious place and external access would have required that the permanently affixed soffit be removed and a mechanism installed to elevate the auditor $20+\mathrm{ft}$. Based on conversations with the contractor, an attic insulation R-value of 1 was used for modeling purposes.

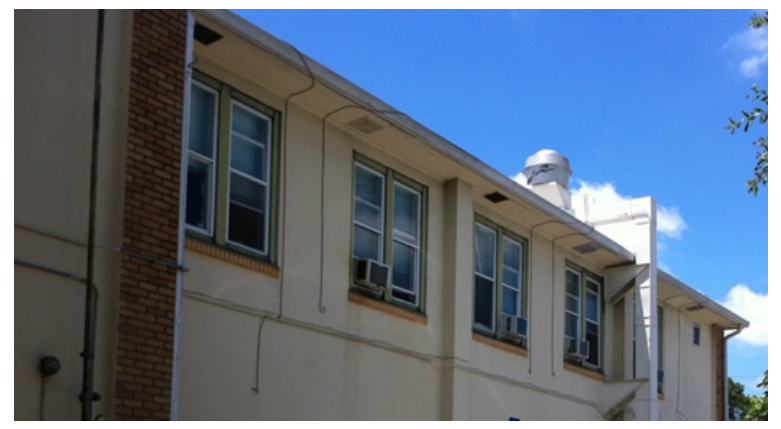

Figure 3. Eaves and vented attic of the Beacon House

The $60 \mathrm{ft} \times 48 \mathrm{ft}$ building consisted of four exterior concrete block walls, void of insulation or stucco finish. Exterior walls were painted a light color, and an estimated solar absorptance of 0.50 was used for modeling purposes.

The 44 windows were clear, single-pane, aluminum-framed glass in various states of disrepair. Assumed efficiency for all windows was a U-value of 1.20 and a solar heat gain coefficient (SHGC) of 0.80 . The 2-ft soffit overhang provided shading for the east- and west-facing windows; the second-story south-facing windows were shaded by awnings. There were five entrance doors, three insulated with a presumed U-value 0.46 , one insulated with a presumed Uvalue of 0.20 , and one glass door. The exterior doors provided opportunities for airtightness through improved weather stripping.

The floor forming the thermal envelope was an uninsulated, slab-on-grade foundation finished with vinyl composition tiles. 


\subsection{Building Airtightness and Ventilation}

A primary source of uncontrolled airflow into and out of the building was through the kitchen, which was ventilated by two built-in exhaust fans (Figure 4). Makeup air was provided by opening the kitchen's exterior door. Because the room was not isolated from the rest of the building, air from the conditioned portions of the building was exhausted through the open kitchen door and exhaust fans.

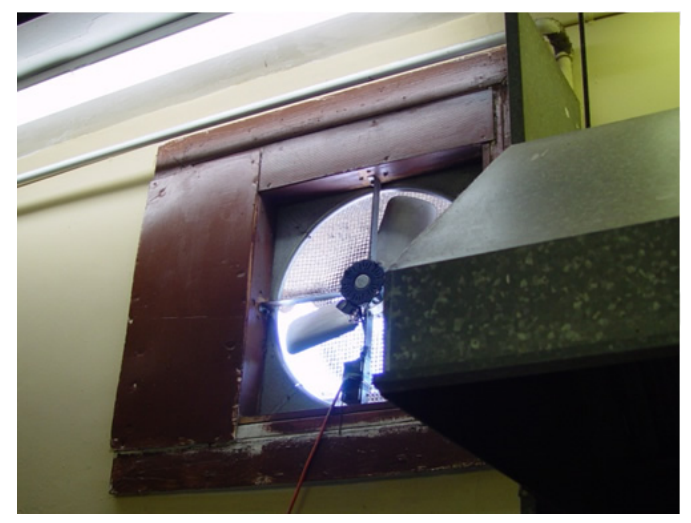

Figure 4. One of two through-the-wall exhaust fans ventilating the kitchen

Whole-house airtightness is calculated as air changes per hour (ACH50) measured at a test pressure of negative $50 \mathrm{~Pa}$ with respect to the outside, divided by the building volume. Researchers were unable to conduct a pre-retrofit whole-building airtightness test, given the previously described kitchen configuration, and the perception that it could not be depressurized. For modeling purposes, researchers estimated whole-building leakage of $\mathrm{ACH} 50=22$ based on normalized results from previous retrofit work involving measurements in existing buildings of similar enclosure characteristics and geographic location (McIlvaine 2010). ${ }^{3}$

\subsection{Mechanical Space Conditioning System}

Two 30-year-old, 108,000-Btu natural gas-fueled furnaces (Figure 5) were used to heat the building and were operated by non-programmable thermostats. The first-floor unit was located in the entrance hallway and the second system in the second-floor mechanical closet. The operational efficiencies for both units were unknown and an annual fuel utilization efficiency (AFUE) of 0.78 was initially used in modeling. The distribution system for the first-floor unit ran between the original ceiling and the newer dropped ceilings. Researchers felt that the air and thermal barriers between the vented attic and dropped ceilings (which contained the ducts) were poor at best; therefore, the pre-retrofit audit indicates the second system's supply ductwork is in attic space.

Twenty-two window air conditioning (AC) systems of various operational conditions were used to cool the entire building. The unknown operational efficiencies were initially modeled to be a mix of energy efficiency ratios (EERs) 7 and 8. As Figure 5 shows, some AC units were poorly fitted, creating additional airflow pathways.

\footnotetext{
${ }^{3}$ After pre-retrofit modeling was completed, a tested ACH50 of 28.7 was achieved by masking off kitchen exhaust fans, proving the original estimate to be conservative.
} 


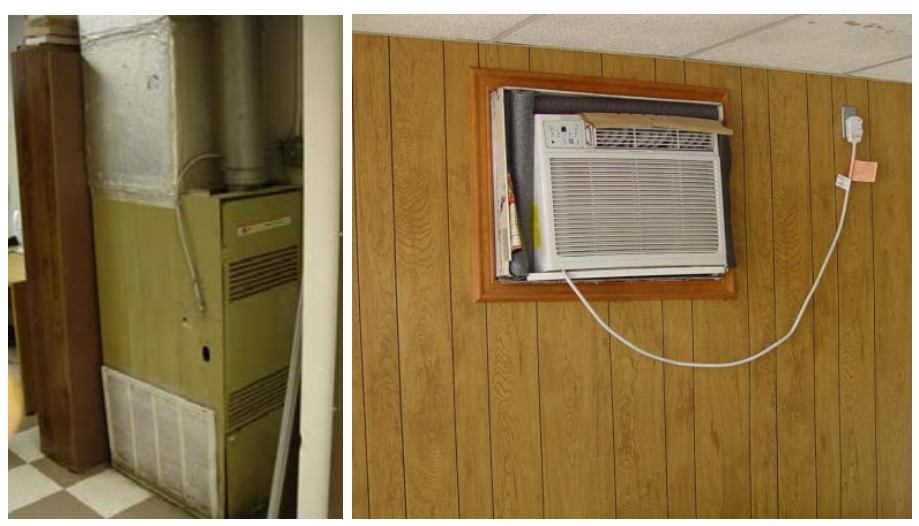

Figure 5. Natural gas furnace (left); window AC unit, fitted into rough opening with cardboard and foam (right)

Duct airtightness can be measured by depressurizing the duct system with a calibrated "duct blaster" fan in accordance with a standard test procedure (RESNET 2012). Duct tightness is expressed in terms of airflow required to achieve a standard test pressure $(25 \mathrm{~Pa})$ in the duct system, measured in cubic feet per minute or CFM25. Leakage involving air to or from unconditioned spaces or the outside is expressed as CFM25,out, and results normalized by conditioned floor area of the building yield Qn,out.

The existing ductwork, located between floors and between the dropped ceiling and the original ceiling below the attic cavity, distributed heat from the gas furnaces. Insulation levels were unknown, but were conservatively estimated to have an R-value of 6 . The pre-retrofit audit did not include a duct tightness test because the building could not be depressurized, which is necessary to determine duct leakage to the outside. For modeling purposes, researchers estimated Qn,out to be 0.22 (McIlvaine 2010).

\subsection{Water Heating System}

The domestic hot water supply consisted of electric resistance tanks: a 120-gal tank servicing the six-shower bathroom, a 40-gal tank supplying the kitchen, and a 20-gal tank that serviced the Americans with Disabilities Act (ADA) accessible bathroom. None of the operational efficiencies were known. But given their apparent age, an efficiency factor (EF) of 0.80 was assumed for all three units.

\subsection{Lighting, Appliances, and Miscellaneous Loads}

Lighting was composed primarily of 4-ft and 8-ft T12 linear fluorescent bulbs with a few incandescent screw type bulbs. Five ceiling fans, of unknown efficiencies, operated throughout the building. Software efficiency defaults were used to model the fans.

Multiple commercial-grade refrigerators (Figure 6) with internal compressor and condenser coils were necessary given the volume of food services. The eight-burner commercial gas stove (Figure 6) was accompanied by an outdoor-venting range hood. There were two sets of coinoperated washers and dryers, one older set and the other relatively new. Simulation software default efficiencies were assumed for both sets. The laundry appliances are available to occupants for personal use and were used twice weekly by facility staff for linens, towels, etc. 

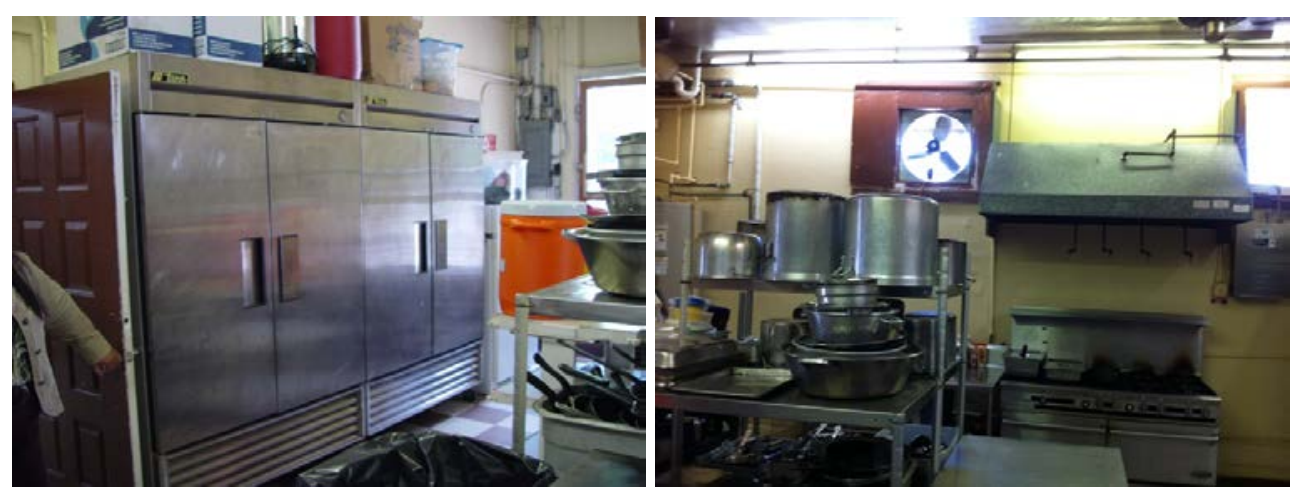

Figure 6. The commercial kitchen (refrigerators, left; range, right) feeds approximately 200 people each night

Miscellaneous loads are influenced by seven computers used by staff and six televisions in the semiprivate rooms and general assembly areas. 


\section{Pre-Retrofit Analysis}

In an effort to improve, or true-up pre-retrofit energy use modeling, researchers obtained Beacon House utility data for one year of pre-retrofit billing. The following information is an account of the utility data analysis, energy use modeling, and simulation true-up conducted to create a baseline energy use model to evaluate Beacon House energy cost saving measure projections.

\subsection{Utility Data Analysis}

Researchers were provided 12 consecutive months of the facility's utility data spanning from August 2010 through July 2011 for electricity and September 2010 through August 2011 for natural gas. To use this data to true-up the pre-retrofit simulation, weather normalization was necessary to align actual utility data with simulation results that use historical weather data. ${ }^{4}$

The first step toward weather normalization was to disaggregate the utility data into energy uses for cooling, heating, and base load - the amount of energy consumed principally when AC and heating are not necessary. Disaggregation was conducted with a simple linear regression based on the best fit between energy use and weather data to separate consumption increases related to cooling and heating needs. Two regressions were run: one to separate cooling energy use, a second for heating energy use. The first regression consisted of 12 months of electricity use as the dependent variable and 12 months of cooling degree days (CDDs) as the independent variable. The second regression was similar, but it consisted of natural gas consumption and heating degree days (HDDs) as the independent and dependent variables, respectively.

Monthly weather data were taken from the National Oceanic and Atmospheric Administration's "Local Climatological Data Publications" for the St. Petersburg area. ${ }^{5}$ Utility billing periods did not align precisely with each calendar month, so calendar month use estimates were created by averaging daily use for each billing cycle and summing the averages for all days in a given month (Table 1). For example, daily averages from the first two billing cycles in Table 1 were used to estimate the consumption for January 2011 by multiplying "days in current bill" and "days in previous bill" by their associated average kilowatt hours $(\mathrm{kWh}) /$ day, and summing these products. The kWh estimate for January 2011 is 6,802 .

Table 1. Sample Utility Billing Periods Used to Estimate Monthly Consumption

\begin{tabular}{c|c|c|c|c|c|c|c|c|c}
\hline \multicolumn{4}{|c|}{ Actual Utility Bill } & \multicolumn{5}{c}{ Calendar Month Estimate } \\
\hline $\begin{array}{c}\text { kWh Bill } \\
\text { Start Date }\end{array}$ & $\begin{array}{c}\mathbf{k W h} \text { Bill } \\
\text { End Date }\end{array}$ & $\begin{array}{c}\text { Actual } \\
\mathbf{k W h}\end{array}$ & $\begin{array}{c}\text { Billing } \\
\text { Days } \\
\text { in } \\
\text { Cycle }\end{array}$ & $\begin{array}{c}\text { Average } \\
\mathbf{k W h} \\
\text { Day }\end{array}$ & Month & $\begin{array}{c}\text { Days } \\
\text { in } \\
\text { Month }\end{array}$ & $\begin{array}{c}\text { Days in } \\
\text { Current } \\
\text { Bill }\end{array}$ & $\begin{array}{c}\text { Days in } \\
\text { Previous } \\
\text { Bill }\end{array}$ & $\begin{array}{c}\mathbf{k W h /} \\
\text { Month }\end{array}$ \\
\hline $12 / 15 / 2010$ & $1 / 7 / 2011$ & 7,104 & 33 & 215 & Dec 10 & 31 & 17 & 14 & 6,940 \\
$1 / 17 / 2011$ & $2 / 15 / 2011$ & 6,491 & 29 & 224 & Jan 11 & 31 & 15 & 16 & 6,802 \\
$2 / 15 / 2011$ & $3 / 16 / 2011$ & 7,269 & 29 & 251 & Feb 11 & 28 & 14 & 14 & 6,643 \\
\hline
\end{tabular}

After the data were organized, the regressions were run. Researchers examined the coefficient of determination $\left(\mathrm{R}^{2}\right)$ results to judge the fit of the model to the data. The results from the linear

\footnotetext{
${ }^{4}$ EGUSA bases its weather data on Typical Meteorological Year 3 (TMY3) weather data

${ }^{5} \mathrm{http}: / /$ www7.ncdc.noaa.gov/IPS/cd/cd.html
} 
regressions, $\mathrm{R}^{2}=0.90$ for the electricity model and $\mathrm{R}^{2}=0.98$ for the gas model, indicate the models' strong predictive values.

An alternative method of estimating utility bills to match the weather periods would be to align weather data with billing periods. Rather than creating monthly use estimates from daily averages, researchers investigated reorganizing daily degree day data into categories precisely matching the utility bill periods. Using daily degree day data removes the error associated with monthly use averages and undoubtedly improves the prediction model. The nearest location of available daily degree data was 20 miles away in Tampa. Unfortunately, the weather data for this location were less similar than researchers hoped. Although daily Tampa data did provide a slightly better prediction of electricity use, the gas use prediction was degraded. For this study, researchers opted to proceed with the previously described calendar month use estimates.

Regression results were then used to predict monthly base load, cooling use, and heating use. The model's resulting line of best fit provides a y-intercept that represents base load: when CDD or HDD, and in turn cooling or heating energy use, is zero. Figures 7 and 8 are plots of the actual and predicted electricity use by CDD and gas use by HDD. For electricity, the constant monthly base load is where the trend line for the regression plot intercepts the $y$-axis, at $6,551 \mathrm{kWh}$. Use exceeding this threshold is associated with increased CDD and is interpreted as cooling load. The regression run with natural gas use produced a monthly base load of 65 therms.

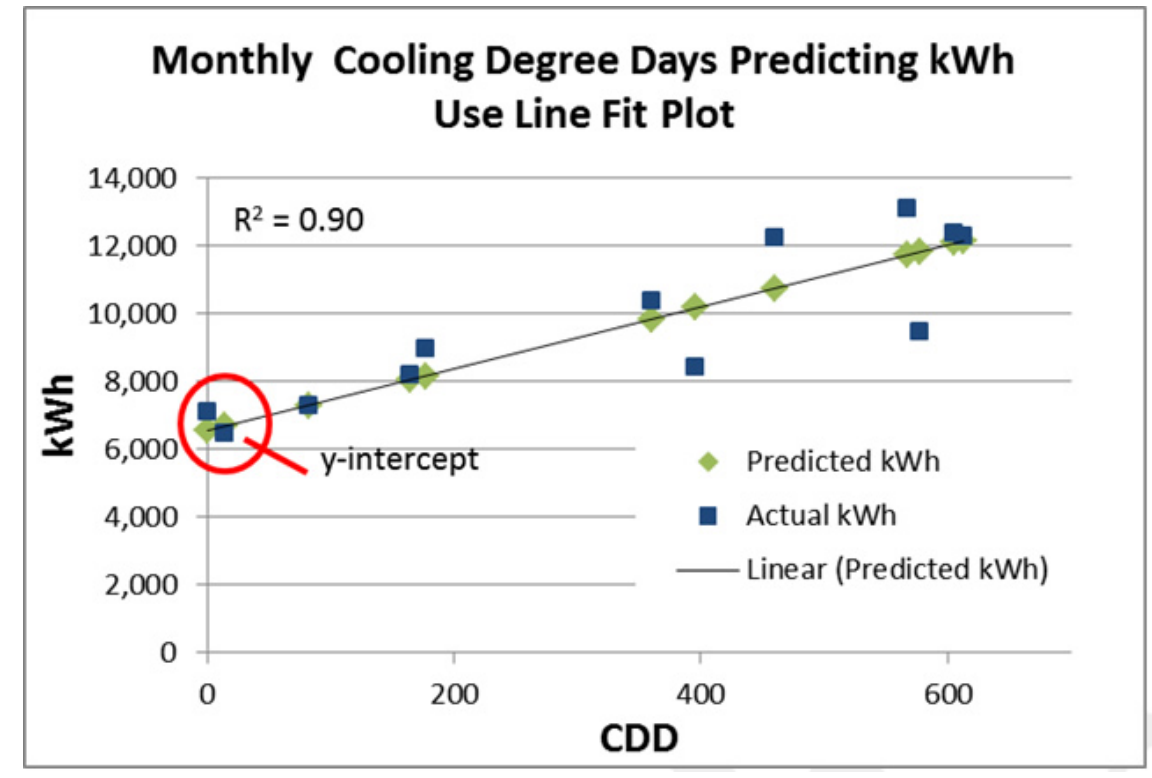

Figure 7. Actual and predicted electricity use by CDD. Y-intercept (base load) at 6,551 kWh. 


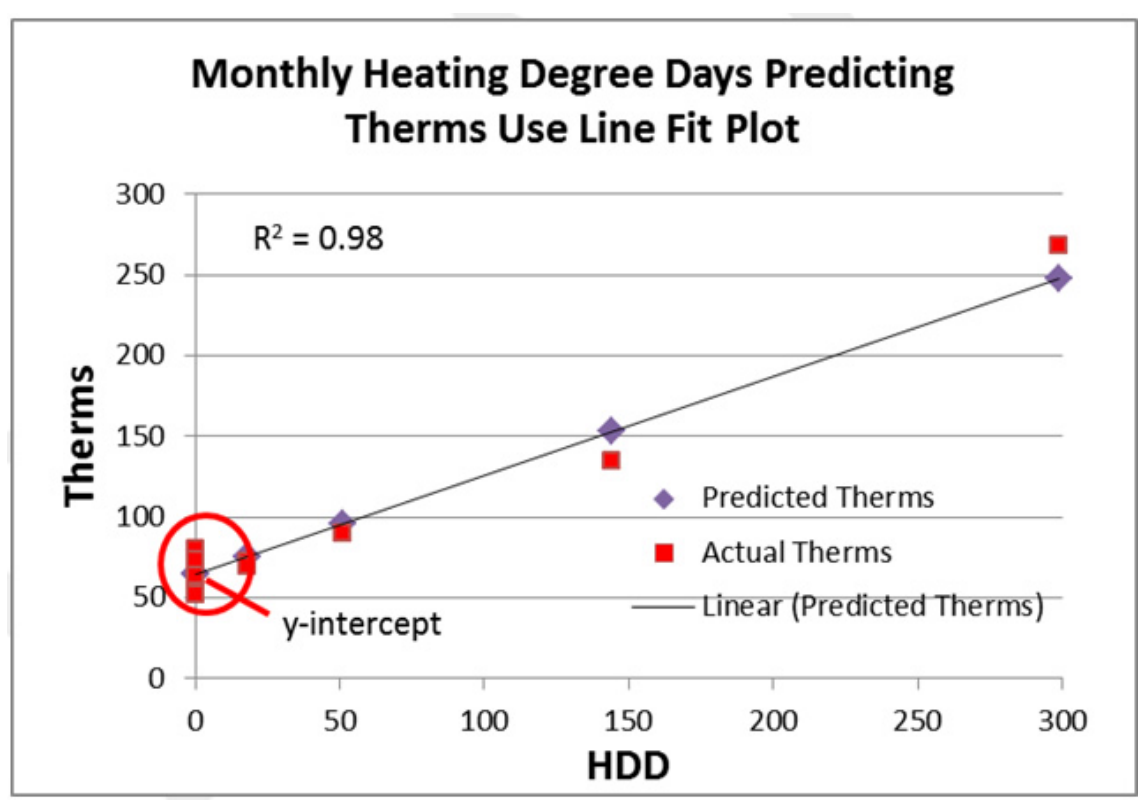

Figure 8. Actual and predicted natural use by HDD. Y-intercept (base load) at 65 therms.

Once cooling and heating use was disaggregated from the base load, monthly use was predicted. Multiplying the independent variable (CDD or HDD) regression coefficient by the CDD or HDD value for each month produces monthly cooling and heating energy for the 2010-2011 utility bill period. Annual base load electricity and natural gas use are 12 times their respective base loads (y-intercept). Results for the annual total disaggregated energy costs are shown in Figure 9, using average Florida utility rates. The large proportion of base load electricity is noteworthy: $58 \%$ of annual utility costs and $71 \%$ of total electricity use.

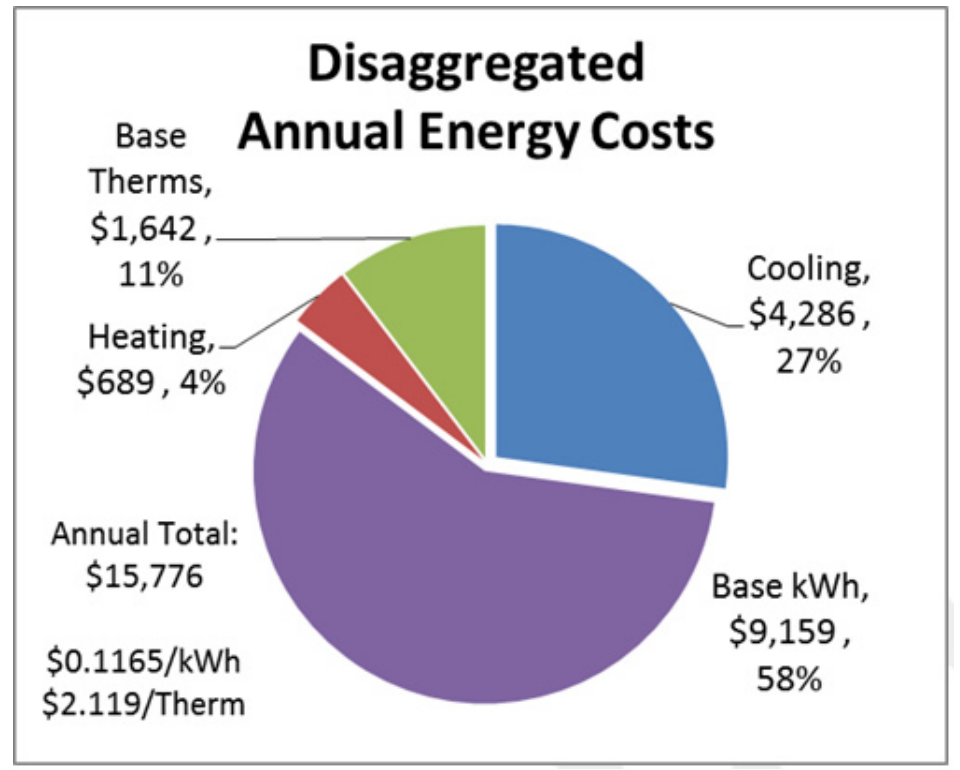

Figure 9. Utility costs disaggregated by heating, base therms, cooling, and base kWh

Monthly energy use and cost predictions were then made as if the building had been subject to Typical Meteorological Year 3 (TMY3) weather data in an effort to align the predictions with 
simulation results. This time, the independent variable (CDD or HDD) regression coefficients were multiplied by the TMY3 CDD or HDD value for each month, to yield weather-normalized results. TMY3 data have 9\% fewer CDDs and 37\% more HDDs. Therefore, predicted cooling use declined, and predicted heating use rose under the weather-normalized assumptions. Because base load estimates were unchanged, the net effect was a decrease in the overall electricity use and an increase in natural gas use, compared to the actual utility data. Figure 10 provides comparisons of end-use energy costs when disaggregated using actual weather and TMY3 weather. The next discussion addresses how the disaggregated, weather-normalized monthly consumption projections were used to true-up the energy use simulation developed in EGUSA.

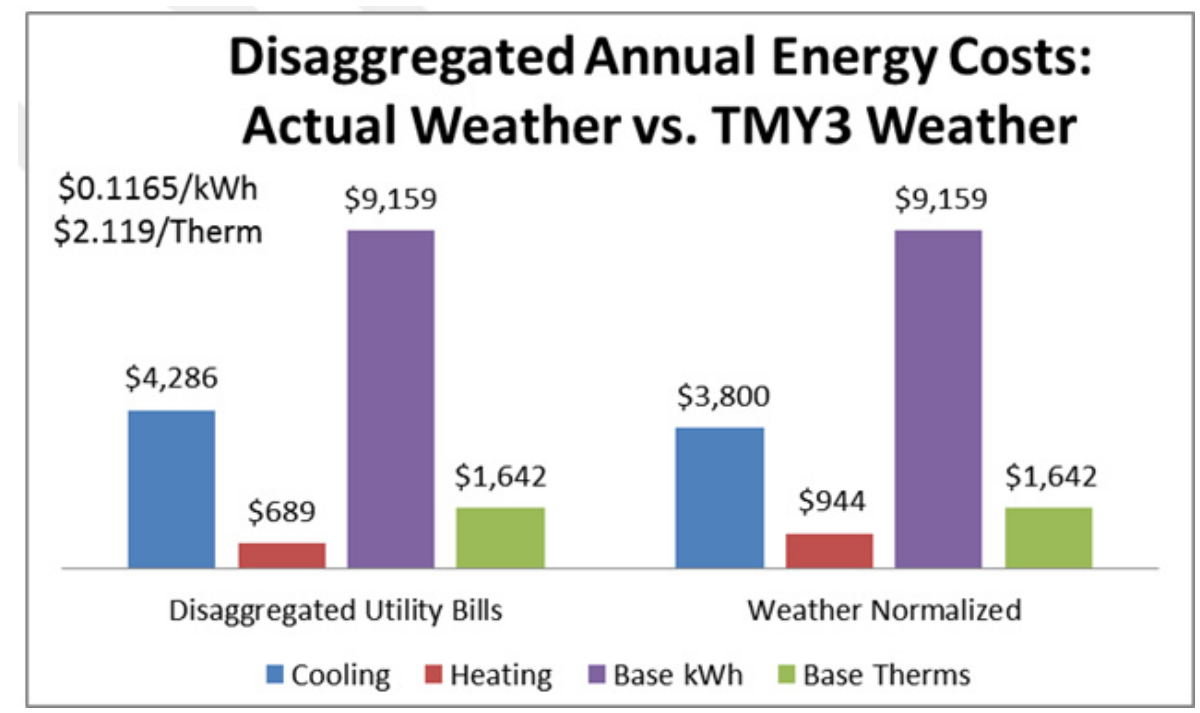

Figure 10. Actual versus TMY3 weather-normalized annual energy costs; changes occur in cooling and heating use only

\subsection{Simulation Development}

Choosing meaningful energy use simulation software for this study was challenging. The Beacon House, which provides transitional housing and commercial food services, presents residential and commercial characteristics that posed energy modeling challenges. Researchers chose to model the building with residential energy simulation software and then modify operational schedules and assumptions based on utility data, the shelter's specific set of services, and the building's unique characteristics. EGUSA was chosen in part because it provides monthly energy end-use reports, which were referenced as part of the simulation true-up exercise.

Location, occupancy, geometry, equipment, efficiencies, etc., obtained from the low-level preretrofit audit were initially characterized in the software with typical residential building patterns and schedules to evaluate pre-retrofit energy use. Results from this simulation are referred to as Initial Base. There are large discrepancies between the weather-normalized energy use and the projected energy use of the Initial Base model, which uses standardized residential assumptions. A comparison of cooling, heating, electricity base load, and natural gas base load (the range) between these two scenarios is referenced in the first two bars of Figure 11. Given that occupancy cannot be traditionally defined (housing and feeding 30 residents and serving 200 meals to the community daily) and the atypical building characteristics (a large, nonisolated, semiconditioned space, and 22 window air conditioners), researchers modified the simulation in 
an effort to more accurately reflect the unique characteristics of the shelter, referred to as the True-Up model (see the third bar of Figure 11).

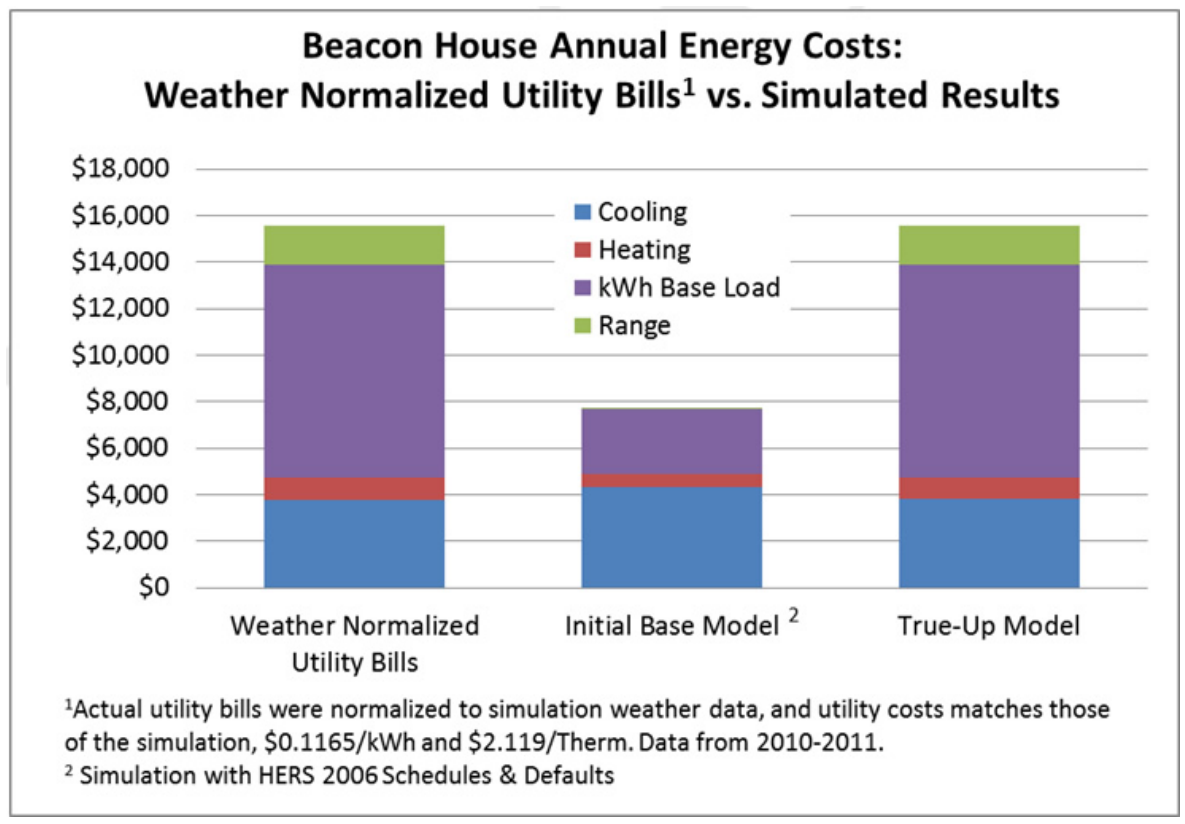

Figure 11. Disaggregated cooling, heating, kWh base load, and therms base load (range)

\subsection{Simulation True-Up}

The disaggregated and weather-normalized utility data described in Section 3.1 provided a guide to adjust appliance uses, equipment efficiencies, schedules, and set points used in the simulation to achieve more accurate results. The simulation's annual summary energy uses were compared to the disaggregated, weather-normalized consumption, which provided four targets: cooling energy, heating energy, electricity base load, and natural gas base load (range).

Consider natural gas consumption first. Using the heating energy projected from the weathernormalized natural gas use as a target, researchers adjusted heating set points and unknown furnace efficiencies until they found the best fit. The remaining gas base load became the annual use of the range, the remaining gas-fueled appliance.

Next consider electricity use. Air conditioner efficiencies and cooling set points were similarly adjusted to produce the cooling energy target derived from the weather-normalized electricity use. The remaining annual use, the base load electricity consumption $(79,000 \mathrm{kWh})$, needed to be distributed among the remaining electricity draws - water heating, refrigeration, lighting, fans, laundry facilities, and miscellaneous loads. Having to apply a great portion of the electricity use (71\%) among these many uses presented a gap in the model and a challenge for researchers. Software defaults using 25 bedrooms, ${ }^{6}$ the HERS 2006 appliance schedule, and software estimates for domestic hot water use based on 30 occupants fell short of this goal by 54,000 kWh.

\footnotetext{
${ }^{6}$ EGUSA produced unpredictable simulation energy use results when number of bedrooms exceeded 25.
} 
Researchers reasoned the water consumption and refrigeration must have been much higher than defaults, as they are heavily influenced by meal services. Annual water consumption was projected to be about twice the simulation's estimated water use for the given occupancy (using $28,000 \mathrm{kWh})$, and commercial refrigeration was estimated at $10 \mathrm{kWh} /$ day $(3,600 \mathrm{kWh} / \mathrm{yr})$.

Lighting was also addressed specifically. Total lighting use was estimated with a bulb inventory and approximation-of-use hours, yielding 27,500 annual $\mathrm{kWh}$. The balance of yearly electricity base load, approximately 19,500 kWh, was distributed among ceiling fans, clothes washing and drying, and miscellaneous loads. A multiplier was applied to the HERS 2006 appliance schedules for the associated end uses, to raise overall projected total annual base load electricity consumption $79,000 \mathrm{kWh}$.

The software simulates whole-house energy use, so altering lighting and appliance schedules impacts heating and cooling loads; therefore, heating and cooling equipment efficiencies and set points were readjusted to mimic the target loads determined through the weather normalization. Thus, an iterative process took place until all four weather-normalized targets were reached. Heating set points were ultimately set to $73^{\circ} \mathrm{F}$ and cooling to $82^{\circ} \mathrm{F}$; the furnace AFUE was 0.71 and $\mathrm{AC}$ window unit efficiencies were a combination of EER 8 and 9. The True-Up model is the product of these simulation adjustments.

Figure 13 shows the weather-normalized consumption for the Beacon House, as well as the Initial Base model and True-Up model pre-retrofit simulations, disaggregated by cooling, heating, electricity base load, and range. The figure reveals how well the True-Up model's cooling, heating, and remaining base load uses mimic the weather-normalized utility data. However, the large purple section of the bars (kWh base load) highlights the model's inability to guide consumption for elements that fall within this category: domestic hot water, refrigeration, lighting, ceiling fan, clothes washer, dryer, and miscellaneous loads.

As a final evaluation of model fit, the weather-normalized and disaggregated utility data were compared to the True-Up model's simulated monthly consumption by end use. Figure 12 displays monthly natural gas and electricity use for the weather-normalized data and the True-Up model. We see good alignment in monthly electricity consumption, varying at most by $13 \%$; the weather-normalized utility data are slightly higher in the swing season months. The natural gas use does not match nearly as well for certain months. This is probably because the weather data used by simulation software actually uses TMY3 data from a nearby, but different location. These differences are often minor, but in the case of a warm climate with relatively few HDDs, a localized cold front can create relatively large monthly differences between nearby locations. As Figure 11 demonstrates, the utility data-backed, weather-normalized simulation clearly provided researchers a more accurate baseline to project annual energy savings. Figure 12 substantiates the model's strength to mimic monthly consumption.

The True-Up model served as the baseline for the post-retrofit cost savings analysis. The proposed retrofit measures are the subject of the next section. 


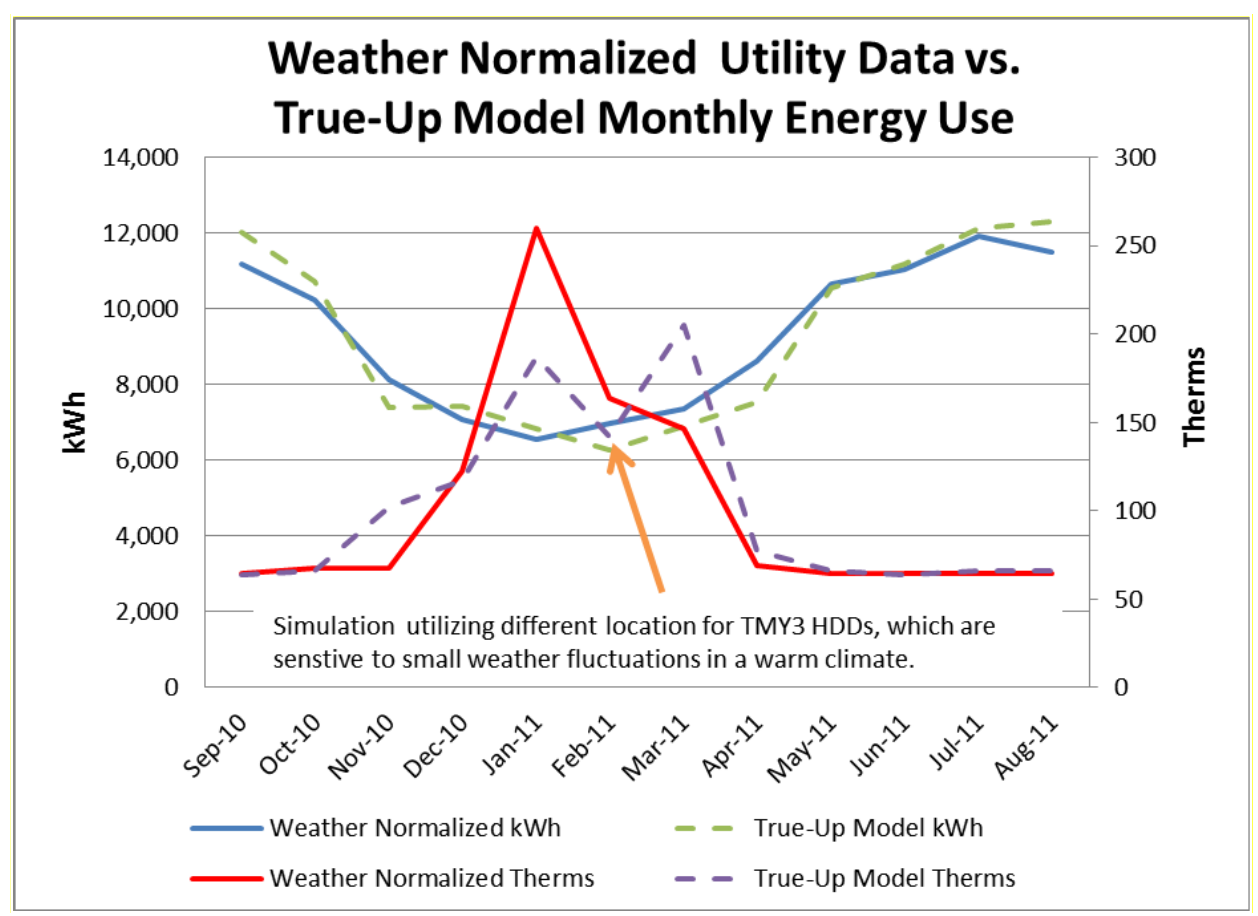

Figure 12. Normalized actual versus simulated monthly energy use. A dip in February simulation therms (purple) results from a warm climate with few HDDs, which is sensitive to localized weather patterns.

\subsection{Proposed Retrofit}

Researchers worked with Matrix to develop the proposed retrofit package estimated to achieve $37 \%$ annual energy savings. The package of improvements is summarized in Table 2. Economics for sets of components appear wherever cost data are combined; e.g., attic insulation and duct location measures.

Attic Insulation and Duct Locations: Recommendations were to remove the tongue-and-groove soffit material, then to work from the perimeter and densely pack the attic cavity between the roof and the dropped ceiling section containing ductwork, with either cellulose or formaldehydefree fiberglass blown-in insulation to achieve an R-value of 38 . The proposed retrofit also included installation of new soffit material and soffit sealing to create a continuous air barrier around the exterior perimeter. This brought the ducts in the cavity below into conditioned space to reduce thermal losses. This measure was projected to save $\$ 792$, or $5.1 \%$ of the total annual bills.

Windows: Window replacement would have been ideal; however, most windows were operational, and with the extensive termite damage around some windows, the energy savings possible from this measure would not have supported the cost, according to the grantor's metrics. Researchers recommended that a window film with an SHGC no higher than 0.40 be applied to all windows. A budget-related decision was to forgo applying film to several windows shaded by trees and overhangs. This measure was projected to save $\$ 162$ annually, or $1 \%$ of the total annual bills. 
Table 2. Proposed Retrofit Package and Predicted Annual Energy Cost Savings ${ }^{a}$

\begin{tabular}{|c|c|c|c|c|c|c|c|c|}
\hline Components & Pre-Retrofit & Proposed Retrofit & $\begin{array}{l}\text { Measure } \\
\text { Cost } \\
\text { Estimate }\end{array}$ & $\begin{array}{l}\text { Projected } \\
\text { Annual } \\
\text { Cost } \\
\text { Savings } \\
\end{array}$ & $\begin{array}{l}\text { Projected } \\
\text { Percent } \\
\text { Savings }^{b}\end{array}$ & $\begin{array}{c}\text { Projected } \\
\text { Annual } \\
\text { kWh } \\
\text { Savings } \\
\end{array}$ & $\begin{array}{c}\text { Projected } \\
\text { Annual } \\
\text { Therms } \\
\text { Savings } \\
\end{array}$ & $\begin{array}{l}\text { Simple } \\
\text { Payback } \\
\text { (Years) }\end{array}$ \\
\hline Roof & $\begin{array}{c}\text { Vented, flat, gravel, } \\
\text { medium color }(0.75 \text { solar } \\
\text { absorptance })\end{array}$ & & & & & & & \\
\hline $\begin{array}{c}\text { Attic } \\
\text { Insulation }\end{array}$ & Insulated at ceiling (R-1) & $\begin{array}{l}\text { Ceiling insulated to } \\
\text { R-38 }\end{array}$ & $\$ 5,600$ & $\$ 792$ & $5.1 \%$ & 4,440 & 130 & 7 \\
\hline $\begin{array}{c}\text { Duct } \\
\text { Locations }\end{array}$ & $\begin{array}{l}\text { System 1: supply, return, } \\
\text { and AHU interior } \\
\text { System 2: supply attic, } \\
\text { return, and AHU interior }\end{array}$ & $\begin{array}{l}\text { Both systems } \\
\text { completely interior }\end{array}$ & & & & & & \\
\hline $\begin{array}{l}\text { Exterior } \\
\text { Walls }\end{array}$ & $\begin{array}{l}\text { Light-colored block walls } \\
\text { (0.50 solar absorptance) }\end{array}$ & & & & & & & \\
\hline Windows & $\begin{array}{c}44 \text { single, clear, metal } \\
\text { frame } \\
(\mathrm{U}-\mathrm{value}=1.20 \\
\mathrm{SHGC}=0.80)\end{array}$ & $\begin{array}{l}\text { Tint all south- and } \\
\text { east-facing windows } \\
\text { to } \mathrm{SHGC} \leq 0.40\end{array}$ & $\$ 750$ & $\$ 162$ & $1.0 \%$ & 3,040 & $(90)$ & 5 \\
\hline Doors & $\begin{array}{c}3 \text { insulated }(\mathrm{U}-\text { value }=0.46 \text {; } \\
1 \text { insulated (U-value } 0.20)\end{array}$ & & & & & & & \\
\hline Floors & $100 \%$ vinyl & & & & & & & \\
\hline $\begin{array}{c}\text { Whole- } \\
\text { House } \\
\text { Infiltration }\end{array}$ & $\begin{array}{c}\text { Compromised envelope } \\
\text { unable to depressurize } \\
\text { (estimated } \\
\text { ACH50 }=22) \\
\text { No ventilation system }\end{array}$ & $\begin{array}{l}\text { Reduced envelope } \\
\text { leakage to average } \\
(\mathrm{ACH} 50=7.87)\end{array}$ & $\$ 6,500$ & $\$ 799$ & $5.1 \%$ & 3,290 & 197 & 8 \\
\hline $\begin{array}{l}\text { Heating and } \\
\text { Cooling } \\
\text { System }\end{array}$ & $\begin{array}{c}22 \text { window units (19 @ } \\
8 \text { EER; } 3 @ 9 \text { EER) } \\
2 \text { gas furnaces; } \\
108 \mathrm{kBtu} / \mathrm{h} \\
\text { (AFUE=0.71) } \\
\text { No programmable } \\
\text { thermostat }\end{array}$ & $\begin{array}{l}2 \text { central units } \\
(\text { SEER 15) } \\
\text { Electric heat pump } \\
\left(\mathrm{HSPF}^{\mathrm{c}}=8.7\right) \\
\text { Programmable } \\
\text { thermostat }\end{array}$ & $\$ 18,000$ & $\$ 2,298$ & $14.8 \%$ & 11,619 & 446 & 8 \\
\hline
\end{tabular}




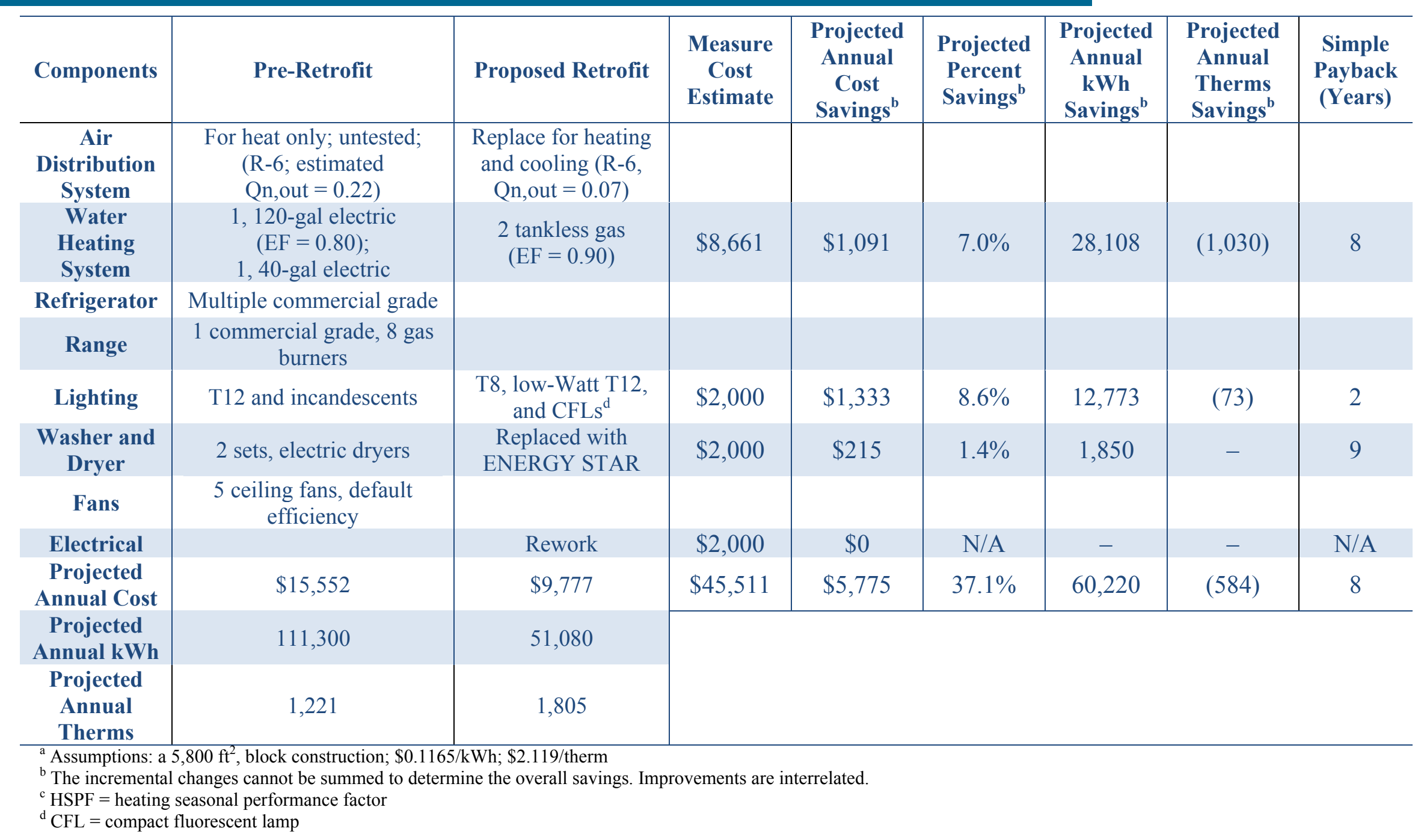


Whole-House Infiltration: The window AC units were removed, the penetrations associated with their removal were sealed, and operational problems were addressed to improve the wholebuilding airtightness. Other measures targeted for leakage reduction included sealing gaps, cracks, and penetrations to the exterior and applying weather stripping to exterior doors and frames.

Air pathways between the conditioned space and the commercial kitchen posed a challenge. As described in Section 2.2, the kitchen was not conditioned, yet not isolated from the rest of the building, wastefully drawing conditioned air away from the main body during exhaust fan operation. Researchers recommended isolating the kitchen from the rest of the building and installing a ductless mini-split to independently condition the kitchen. The contractor agreed to isolate the kitchen by applying weather stripping to the two interior kitchen doors, but rejected conditioning the area because of the expense.

Sealing airflow pathways and isolating the kitchen were estimated to reduce the whole-building leakage to about $\mathrm{ACH} 50=8$. Given the age and construction of the building, and the limited extent of the retrofit, post-retrofit airtightness levels were not expected to reach levels that would suggest a need to implement supplemental mechanical ventilation. The projected annual cost savings associated with all these building tightening steps was $\$ 799,5.1 \%$ of the total annual cost.

Heating, Cooling, and Air Distribution Systems: The AC and heating systems needed to be completely replaced. Researcher recommendations were to replace all the window AC units and the gas furnaces with two forced-air, central heat pumps with a seasonal energy efficiency ratio (SEER) of 15 and an HSPF of 8.7 or greater. Programmable thermostats were also recommended.

A complete replacement of the air distribution system with a new system having an R-value of 6 or more was recommended to accommodate the new central heat pumps. Researchers anticipated duct leakage would be reduced from the pre-retrofit estimate of Qn,out $=0.22$ to 0.07 as a result of the complete mechanical system replacement (McIlvaine 2010). These combined measures were projected to save $\$ 2,298$ annually, or $14.8 \%$ of the total annual bills.

Water Heating System: Researchers recommended replacing the electric water heating systems with high-efficiency, natural gas-fueled tankless or electric heat pump water heaters. Given the building's excessive water heating demands from 30+ occupants and extensive food services, the contractor chose high-capacity, natural gas-fueled, tankless units. The subcontractor specified two units, given the load capacity required to concurrently operate showers, washing machines, and to allow for the kitchen's needs. Gas lines and additional plumbing would need to be installed as a result of the fuel conversion and appliance relocations. The water heating measure was projected to save $\$ 1,091$ annually, for a $7 \%$ reduction to the total annual cost.

Lighting and Appliances: All light fixtures were slated to be replaced with energy-efficient lighting products. A high-efficiency replacement for the older of the two washer and dryer sets was recommended. Researchers specified the washing machine be ENERGY STAR-certified. The lighting and appliance measures were projected to save $\$ 1,333$ and $\$ 215$ respectively, for a combined total annual cost savings of $10 \%$. 
Electrical: An update to the building electrical system was deemed essential. This cost was included as part of the energy efficiency retrofit analysis, because some level of electrical retrofit was required to change from the gas furnaces to heat pumps.

As presented at the bottom of Table 2, in comparison to the pre-retrofit, weather-normalized, True-Up pre-retrofit model, electricity use is expected to be reduced by $60,220 \mathrm{kWh}$ annually; gas use is predicted to rise by 584 therms. The water heating fuel switch is responsible for the increase in gas consumption. The projected annual energy cost savings from all these measures was $\$ 5,775$, a reduction of $37 \%$, which is slightly below the funding program goal of $40 \%$. The overall simple payback of eight years was longer than the funding program goal of five years. Although savings and payback projections fell slightly short of the funding program target metrics, the Beacon House project funding was awarded. 


\section{Characteristics of Post-Retrofit Energy Improvements}

In June 2012, researchers visited the Beacon House to interview staff and contractors and to conduct a post-retrofit audit. The staff reported that they were very pleased with the retrofit. They also said that the work was done well and very quickly. Contractors worked around Beacon House staff schedules and did not disrupt the residents or the community. Table 3 provides a summary of the seven retrofit measures taken. Measure economics are presented in Section 5.1. The following discussion is a measure-by-measure description of the audit findings.

Table 3. Post-Retrofit Findings by Measure ${ }^{a}$

\begin{tabular}{|c|c|c|}
\hline Components & Pre-Retrofit & Post-Retrofit \\
\hline Attic Insulation & Insulated at ceiling $(\mathrm{R}-1)^{\mathrm{b}}$ & $\begin{array}{c}\text { Ceiling insulated to R-34; R-1 for } \\
\text { south } 15 \mathrm{ft}\end{array}$ \\
\hline Duct Locations & $\begin{array}{l}\text { System 1: Supply, return, and } \\
\text { AHU interior; } \\
\text { System 2: Supply attic, return, } \\
\text { and AHU interior }\end{array}$ & Both systems completely interior \\
\hline Windows & $\begin{array}{l}44 \text { single, clear, metal frame }(\mathrm{U}- \\
\text { value }=1.20 ; \mathrm{SHGC}=0.80\end{array}$ & $\begin{array}{l}\text { Film on first floor south, all east- and } \\
\text { west-facing windows to SHGC } \leq 0.37\end{array}$ \\
\hline $\begin{array}{l}\text { Whole-House } \\
\text { Infiltration }\end{array}$ & $\begin{array}{l}\text { Compromised envelope unable } \\
\text { to depressurize } \\
\text { (estimated ACH50 = 22) }\end{array}$ & $\begin{array}{l}\text { Reduced envelope leakage ACH50 to } \\
8.8 \text { (based on } \sim 5,300 \mathrm{ft}^{2} \text { ) }\end{array}$ \\
\hline \multirow[t]{2}{*}{$\begin{array}{l}\text { Heating and } \\
\text { Cooling System }\end{array}$} & \multirow[t]{2}{*}{$\begin{array}{c}22 \text { window units } \\
\text { (19@ EER 8; } 3 @ \text { EER 9) } \\
2 \text { gas furnaces; } 108 \mathrm{kBtu} / \mathrm{h} \\
\text { (AFUE 0.71) } \\
\text { No programmable thermostat }\end{array}$} & $\begin{array}{l}2 \text { central units (SEER 15) } \\
\text { Electric heat pump }(\text { HSPF }=8.7)\end{array}$ \\
\hline & & Programmable thermostat \\
\hline $\begin{array}{l}\text { Air Distribution } \\
\text { System }\end{array}$ & $\begin{array}{c}\text { For heat only, untested } \\
\text { (R-6; estimated Qn,out }=0.22 \text { ) }\end{array}$ & $\begin{array}{l}\text { Replace for heating and cooling } \\
\qquad(\mathrm{R}-6 \text {; Qn,out }=0.02)\end{array}$ \\
\hline $\begin{array}{l}\text { Water Heating } \\
\text { System }\end{array}$ & $\begin{array}{c}1,120 \text {-gal electric }(\mathrm{EF}=0.80) \\
1,40 \text {-gal electric }(\mathrm{EF}=0.80)\end{array}$ & 2 tankless gas $(\mathrm{EF}=0.82)$ \\
\hline Lighting & T12 and incandescent & T8, low-Watt T12, and CFLs \\
\hline Washer and Dryer & 2 sets, electric dryers & 1 replaced with ENERGY STAR ${ }^{\mathrm{c}}$ \\
\hline Electrical & & Rework \\
\hline
\end{tabular}

${ }^{a}$ Assumption: $5,800 \mathrm{ft}^{2}$, block construction.

${ }^{\mathrm{b}}$ Pre-retrofit condition of $\sim \mathrm{R}-7$ was determined during retrofit.

${ }^{\mathrm{c}}$ Washer and dryer set to be replaced after lease expires.

\subsection{Attic Insulation and Duct Locations}

With no viable interior attic access, the soffits were removed to allow contractors to blow in dense pack cellulose. Contractors found that the attic cavity did have some limited insulation, estimated to be R-7, unlike the R-1 value, which was used for pre-retrofit modeling. New insulation was blown in over this 2 in. of compressed, blown-in fiberglass insulation. The cavity depth was not large enough to accommodate an R-38, so an R-value of 34 was achieved. The unsoffitted, south $15 \mathrm{ft}$ of the building was not accessible and therefore went uninsulated. The approach of insulating the attic via the soffits was chosen over other methods (insulating from below via holes in the ceiling) to minimize disruption to the facility, as it remained occupied 
during the entire retrofit. To reach the soffits, Matrix chose to use a high lift, rather than ladders, to mitigate the risk of injury. The soffit material was replaced with $1 / 2$-in. plywood that was sealed with urethane to create an unvented attic, then primed and painted.

Researchers did not revise the pre-retrofit analysis and true-up based on the contractor's findings during the retrofit, because the retrofit scope had already been finalized based on the original analysis. The effect of incorrect assumptions on the savings analysis is minimized as a result of the true-up to actual utility data. Lack of access to the attic during the pre-retrofit audit overestimated the projected savings associated with this measure in three ways:

1. The pre-retrofit assumption was that insulation could be added to the entire ceiling thermal boundary. However, contractors were unable to access the front $15 \mathrm{ft}$ of the building's ceiling, so the presumed post-retrofit improvement greatly exceeded reality.

2. Pre-retrofit modeling assumed attic insulation with an R-value of 1 . Observations during the retrofit suggest that the insulation was nearer an R-7; therefore, the projected improvement for this measure was overstated by the presumed less-efficient pre-retrofit condition.

3. Energy auditors assumed that there was adequate attic space to support enough densely packed cellulose to attain an R-value of 38, whereas only R-34 was possible; therefore, the projected improvement for this measure overstated the attainable post-retrofit condition.

\subsection{Windows}

Window film with a shading coefficient of 0.43 (SHGC $\sim 0.37$ ) was applied to the inside of all but the second floor, south-facing windows, despite the original plan for a more limited application. Funding to film the additional windows came directly from the Beacon House, outside the HomeAid grant. The windows that were not filmed are well shaded by deep awnings. At the time of this report, Matrix reported that it would consider applying film to the remaining windows as part of an effort to address cooling issues in two offices with untreated windows. The yet unresolved cooling issue is discussed in Section 4.5.

\subsection{Whole House Infiltration}

As described in Section 2.3, the removal of the window AC units provided a great opportunity for whole-house leakage reduction by eliminating the airflow pathways around and through the equipment. Upon removal, contractors discovered that three windows were not operational, which the Beacon House gave Matrix permission to permanently seal closed. Although permanently sealing windows limits egress, it was not an issue with code enforcement. Other measures taken to reduce whole-house leakage included applying a urethane seal to exterior and an acrylic seal to interior window penetrations and resealing around window framing, sealing all visually observed penetrations to the building's exterior, and sealing the soffits as described in Section 4.1. Weather stripping was applied to all exterior doors and, in an effort to thermally isolate the kitchen, to the interior kitchen doors. Post-retrofit blower door test results showed whole-building leakage to be $\mathrm{ACH} 50=8.8$. Researchers excluded the kitchen area from the test because it is well connected to the outdoors, and depressurized the building with the kitchen doors closed. 
During the whole-house depressurization test, researchers identified additional leakage sourcesthe edges of the attic hatch, around the interior kitchen doors where the weather stripping detail needed to be readdressed, and an open wall cavity in the second floor air handling unit (AHU) closet (Figure 13).

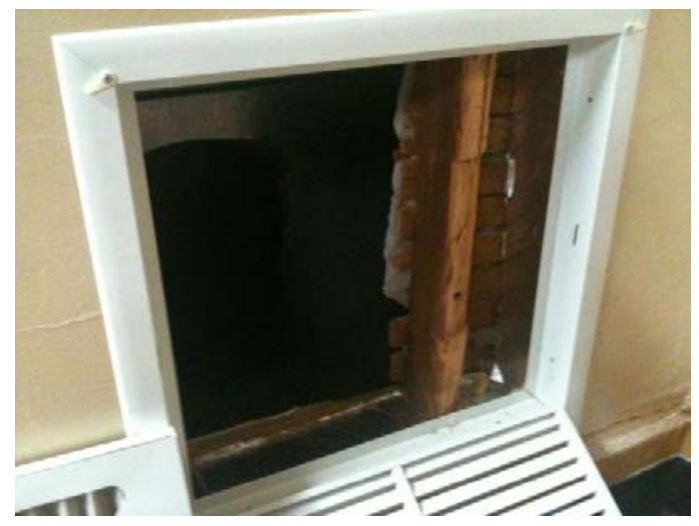

Figure 13. Post-retrofit, researchers observed an airflow pathway from a large open wall cavity between the AHU and the filter grille

\subsection{Heating, Cooling, and Air Distribution Systems}

Two five-ton SEER 15 HSPF 8.7 forced air, central heat pumps replaced the 22 window AC units and two gas furnaces, as recommended. The Air Conditioning Contractors Association standardized Manual J sizing procedure considering post-retrofit specifications was used for heating and cooling load calculations. Programmable thermostats were installed for each system. The ground floor AHU is shown in Figure 14. Matrix reported a seamless installation, including the fuel change, which required capped gas lines. Electrical upgrades were essential to accommodate the electric resistance backup.

As testament to the effective work done by Matrix and its mechanical contractor, the Beacon House staff was pleased to see that the AC systems were removed and replaced in one week. Anecdotally, one semiprivate room resident expressed great pleasure with the more comfortable environment since the retrofit.

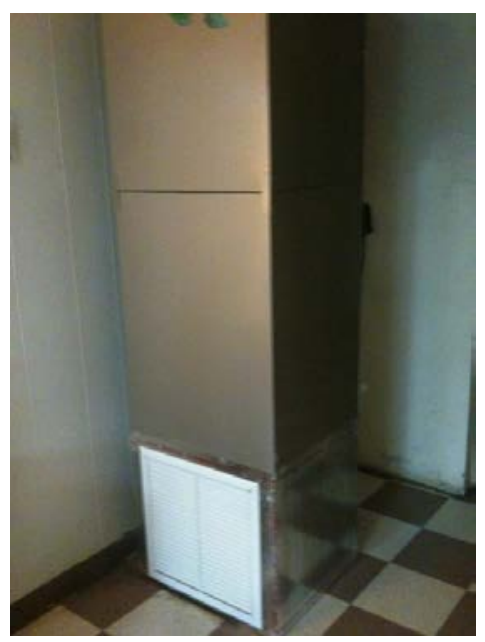

Figure 14. Post-retrofit ground floor, SEER 15 heat pump AHU 
Although the original retrofit plan included duct replacement, access for installation was limited. Instead, contractors added a new trunk line to the ducts to allow more return air from the dormitory room, to balance supply and return air to all spaces and improve comfort. The new R6 insulated return run was attached with mesh and mastic and installed between floors and into penetrations made in the internal block walls. Previous renovations in the ceiling restricted access to some areas of the building and structural degradation from termite damage created a retrofit challenge of limited options to locate duct runs.

After HVAC upgrades staff reported that the two second-floor offices were still not cooling adequately. Undoubtedly, this was in part due to the lack of ceiling insulation above these rooms (see Section 4.1) and the high occupancy level. Access to the duct servicing this section of the building was limited and not economically feasible. During the post-retrofit audit, researchers tested the room pressures with respect to the main body while the mechanical system was running and found these two offices to be slightly positively pressurized (1 and $0.9 \mathrm{~Pa}$ ). However, the large dormitory, serviced by the same supply line just before these offices, was positive 6.2 $\mathrm{Pa}$. Researchers recommended that contractors reduce the amount of conditioned air being delivered to the dormitory to make it less positively pressurized and force more conditioned air into the problem rooms. Further, researchers recommended return air pathways be installed in the front offices and the semiprivate rooms to help balance pressures and temperatures throughout the building. As of the time of this report, contractors had restricted the amount of air being delivered to the dormitory, but this was not sufficient to provide adequate comfort to the offices. Matrix was continuing the investigation to correct the issue and considering installing new supply duct lines to these rooms.

Post-retrofit duct leakage tests revealed the retrofitted duct system to be essentially devoid of leakage to the outside. The large penetration between the return plenum duct board and the wall cavity in the second-floor AHU closet was masked during duct testing (Figure 15). Matrix agreed to seal this access; however, masking this area for testing may have yielded better results than the eventual state. The first floor system duct leakage test results were Qn,out $=0.006$, and the second floor system test results were Qn,out $=0.03$. The combined results of the mechanical system change-outs and the duct retrofit yielded a significantly reduced duct leakage from the assumed pre-retrofit condition of Qn,out $=0.22$.

\subsection{Water Heating System}

Two externally mounted, natural gas water heaters (Figure 15) replaced the three electric tank units. This was an expensive retrofit measure because the gas piping servicing the building needed to be upgraded and water lines rerun to accommodate the new water heater locations. The EF for the new water heaters was 0.82 , less efficient than the 0.90 recommendation. Matrix indicated the priority was finding equipment with the highest available capacity to accommodate the facility's large water heating demands. 


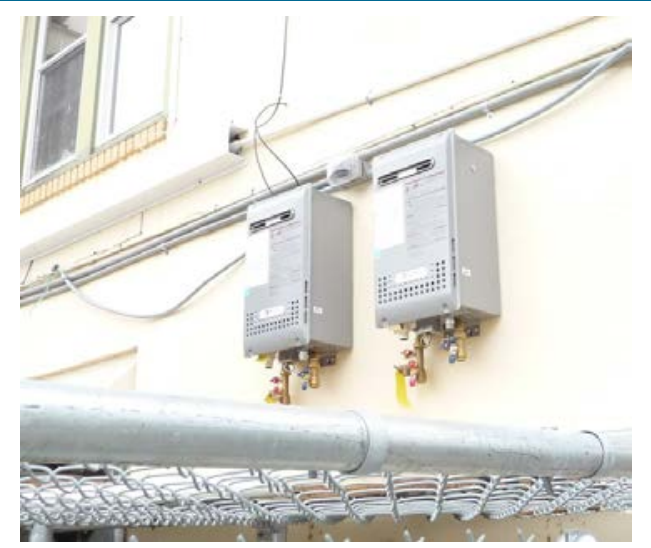

Figure 15. Two externally mounted gas tankless water heaters

\subsection{Lighting and Appliances}

The lighting retrofit was incomplete during the post-retrofit audit, but complete replacement of all light fixtures with energy-efficient lighting products was being completed as proposed. This includes exchange of all incandescent light bulbs with compact fluorescent lamps (CFLs) in the bedrooms, some bathrooms, the laundry room, and two of the offices; 40-W T8 linear fluorescent tubes in the heavily used kitchen, kitchen hall area, and kitchen storage areas; and 34-W T12 linear fluorescent tubes throughout the remainder of the building.

Though one clothes washer and dryer set was slated for immediate replacement, Matrix discovered that the units were being leased by Beacon House for another year. For this study, researchers assumed the eventual purchase of efficient appliances, including an ENERGY STAR-certified washing machine. 


\section{Post-Retrofit Energy Cost Savings and Cost Effectiveness}

Once the post-retrofit energy audit was completed, researchers recreated the energy use simulation in EGUSA reflecting the actual post-retrofit findings and test results. Simulation savings projections are accompanied by pre-retrofit cost estimates provided by Matrix. The Beacon House retrofit economics are provided in Table 4, which is a lateral extension of Table 3 in Section 4. This table provides the same metrics provided in Table 2 (measure cost, projected annual cost savings, projected percent savings, projected annual $\mathrm{kWh}$ and therms savings, and simple payback) and discussed in Section 3.4, in addition to an SIR for each measure. SIR calculations are those recently adopted by RESENT (RESNET 2012). For this analysis, a sevenyear mortgage period was assumed. See the Appendix for all SIR calculation assumptions.

Incremental costs are sometimes used for evaluating cost effectiveness when a higher efficiency specification is selected for replacement of an item at the end of its life. As a prime example, assuming an air conditioner is at the end of its life, the incremental cost for installing a highefficiency system is the cost difference between the chosen unit and the least costly system available. Simple payback can be considerably shortened when considering only incremental costs. Although some of the Beacon House building components and appliances appeared to be operating beyond their useful lives, the metrics established by the funding organization address full costs only and incremental costs were not used in that analysis. However, researchers considered first costs and incremental costs in the SIR calculations for appropriate Beacon House retrofit measures. 
Table 4. Post-Retrofit Measure and Package Costs and Savings ${ }^{a}$

\begin{tabular}{|c|c|c|c|c|c|c|c|c|}
\hline Components & Post-Retrofit & $\begin{array}{l}\text { Measure } \\
\text { Cost }\end{array}$ & $\begin{array}{c}\text { Projected } \\
\text { Annual } \\
\text { Cost } \\
\text { Savings } \\
\end{array}$ & $\begin{array}{c}\text { Projected } \\
\text { Percent } \\
\text { Savings }\end{array}$ & $\begin{array}{c}\text { Projected } \\
\text { Annual } \\
\text { kWh } \\
\text { Savings } \\
\end{array}$ & $\begin{array}{c}\text { Projected } \\
\text { Annual } \\
\text { Therms } \\
\text { Savings } \\
\end{array}$ & $\begin{array}{c}\text { Simple } \\
\text { Payback } \\
\text { (Years) }\end{array}$ & SIR \\
\hline Attic Insulation & $\begin{array}{l}\text { Ceiling insulated to R-34; R-1 for } \\
\text { south } 15 \mathrm{ft}\end{array}$ & $\$ 5,600$ & $\$ 228$ & $1.5 \%$ & 890 & 59 & 25 & 0.44 \\
\hline Duct Locations & Both systems completely interior & & & & & & & \\
\hline Windows & $\begin{array}{l}\text { Film on first floor south; all east- } \\
\text { and west-facing to SHGC } \leq 0.37\end{array}$ & $\$ 750$ & $\$ 188$ & $1.2 \%$ & 3,000 & $(75)$ & 4 & 2.08 \\
\hline $\begin{array}{l}\text { Whole-House } \\
\text { Infiltration }\end{array}$ & $\begin{array}{l}\text { Reduced envelope leakage ACH50 } \\
\text { to } 8.8 \text { (based on } \sim 5,800 \mathrm{ft}^{2} \text { ) }\end{array}$ & $\$ 6,500$ & $\$ 739$ & $4.8 \%$ & 2,900 & 185 & 9 & 1.18 \\
\hline $\begin{array}{l}\text { Heating and } \\
\text { Cooling System } \\
\text { Air } \\
\text { Distribution } \\
\text { System }\end{array}$ & $\begin{array}{c}2 \text { central units (SEER 15) } \\
\text { Electric heat pump }(\mathrm{HSPF}=8.7) \\
\text { Programmable thermostat } \\
\text { Replace for heating and cooling (R- } \\
\text { 6; Qn,out }=0.02)\end{array}$ & $\$ 18,000$ & $\$ 2,530$ & $16.3 \%$ & 13,614 & 446 & $\begin{array}{l}\text { Full }^{\text {b }}: 7 \\
\text { Inc }^{\text {b }}: 1\end{array}$ & $\begin{array}{l}\text { Full: } 1.15 \\
\text { Inc: } 5.93\end{array}$ \\
\hline $\begin{array}{l}\text { Water Heating } \\
\text { System }\end{array}$ & 2 tankless gas $(\mathrm{EF}=0.82)$ & $\$ 8,661$ & $\$ 875$ & $5.6 \%$ & 28,108 & $(1,131)$ & 10 & 0.57 \\
\hline Lighting & T8, low-Watt T12, and CFLs & $\$ 2,000$ & $\$ 1,333$ & $8.6 \%$ & 12,773 & $(73)$ & 2 & 2.95 \\
\hline $\begin{array}{l}\text { Washer and } \\
\text { Dryer }\end{array}$ & $\begin{array}{l}1 \text { replaced with } \\
\text { ENERGY STAR }^{\mathrm{c}}\end{array}$ & $\$ 2,000$ & $\$ 215$ & $1.4 \%$ & 1,850 & - & 9 & 0.88 \\
\hline Electrical & Rework & $\$ 2,000$ & $\$ 0$ & $\mathrm{~N} / \mathrm{A}$ & - & - & N/A & N/A \\
\hline $\begin{array}{l}\text { Projected } \\
\text { Annual Cost }\end{array}$ & $\$ 10,177$ & $\$ 45,511$ & $\$ 5,375$ & $34.6 \%$ & 58,626 & $(685)$ & 8 & $\begin{array}{l}\text { Full: } 0.91 \\
\text { Inc: } 1.29\end{array}$ \\
\hline $\begin{array}{c}\text { Projected } \\
\text { Annual kWh }\end{array}$ & 52,674 & & & & & & & \\
\hline $\begin{array}{c}\text { Projected } \\
\text { Annual Therms }\end{array}$ & 1,906 & & & & & & & \\
\hline
\end{tabular}




\subsection{Measure Cost Savings and Cost Effectiveness}

Attic Insulation and Duct Locations: Annual energy cost savings associated with the attic insulation and soffit sealing measure is projected to be $\$ 228$ annually, or $1.5 \%$ of the total annual utility costs. This measure comes with a lengthy simple payback of 25 years. Looking to break even between cost and benefit, an SIR value of 1.0 or higher is desired for each measure, meaning the present day value of savings is at least equal to its cost. With an SIR of 0.44, the insulation and duct location measure fails this metric. Had the contractor been able to access the front $15 \mathrm{ft}$ of the building's attic, break-even cost would have easily been achieved.

Windows: Because more windows were filmed than planned, the proposed projected annual energy cost savings associated with the window film measure was slightly exceeded. This measure saves $\$ 188$ annually, or $1.2 \%$ of the total annual utility costs. The simple payback for this measure is just four years. Although the measure provides only small energy cost savings, with an SIR of 2.08, it is a valuable part of the retrofit package.

Whole-House Infiltration: Projected energy cost savings associated with the infiltration reduction is $\$ 739,4.8 \%$ of total annual energy costs. This measure has a projected simple payback of nine years. Although the cost for these air sealing measures was high, great savings are projected driving the SIR above break-even cost, to 1.18.

Heating, Cooling, and Air Distribution Systems: Projected annual energy cost savings of the entire heating and cooling system upgrade, which included installation of programmable thermostats, is $\$ 2,530,16.3 \%$ of the total annual utility costs. The combined simple payback for these measures is seven years. An SIR of 1.15 narrowly surpasses break-even. Yet, arguably only incremental costs should be included in the SIR calculation because the pre-retrofit systems did not adequately provide comfort to the occupants. Assuming only incremental costs from SEER 13 straight-cool resistance heat systems to SEER 15 heat pumps, plus the cost of two programmable thermostats and the ductwork retrofit, researchers estimate a much higher SIR of 5.93 and a simple payback of one year. These projections are weakened, however, by the unknown pre-retrofit duct condition and location.

Such low post-retrofit leakage on distribution systems that were not entirely replaced put into question the pre-retrofit leakage assumption of Qn,out $=0.22$. However, even with the centralized control, a cooling set point of $72^{\circ} \mathrm{F}$ was observed during the post-retrofit audit. This temperature is $10^{\circ} \mathrm{F}$ cooler than the set point estimated for the pre-retrofit condition through the true-up exercise (see Section 3.3). Although the $82^{\circ} \mathrm{F}$ pre-retrofit set point was used to true-up estimated cooling energy use rather than to reflect an actual condition, the observed post-retrofit set point is certainly expected to diminish the projected savings. To counteract this, training has been recommended to educate staff on the effect of set point on space conditionoing energy use. For every degree the thermostat is lowered during the cooling season, a 10\% increase in cooling energy can be expected.

Water Heating System: The tankless gas water heaters are projected to save $\$ 875$ annually, a $5.6 \%$ reduction in total annual energy costs, and the simple payback is 10 years. Installation costs included a fuel conversion and new plumbing lines, essentially doubling the cost of this measure. As a result, the SIR is 0.57 , well below break-even for this metric. Although the existing units 
were older, all were in working condition. Thus, an SIR based on incremental costs was not calculated.

Lighting and Appliances: The lighting retrofit is projected to save $\$ 1,333$ annually, $8.6 \%$ of the total annual energy costs. The expected payback is just two years, and the SIR of 2.95 demonstrates great value. Replacing the leased washer and dryer with the new purchase is projected to save $\$ 215$ annually, or $1.4 \%$ of total energy costs. Researchers project a nine-year simple payback. An SIR calculation with incremental cost is not appropriate because the old equipment was leased. The lease fee is one half of the revenue generated by these coin-operated machines. For the purposes of this SIR calculation, researchers treated the appliances as if they were owned.

\subsection{Summary of Cost Effectiveness}

As presented at the bottom of Table 4, in comparison to the pre-retrofit weather-normalized True-Up model, the projected annual energy cost savings expected from the Beacon House retrofit is nearly $35 \%$, with projected savings of $\$ 5,375$. The anticipated simple payback is eight years. Electricity use is expected to be reduced by $58,626 \mathrm{kWh}$ annually; the projected gas use will rise because of the fuel switch to natural gas water heating. The overall savings falls just short of the funding program goal of $40 \%$ savings and a five-year simple payback. Including the costs for the electrical upgrade, the cumulative SIR for the retrofit package assuming all full improvement costs is 0.91. Adjusting for incremental costs (HVAC), the cumulative SIR rises above break-even to 1.29 .

Savings were lost because the attic could be insulated only to an R-value of 34, where it was accessible, and much of it was inaccessible. Strictly regarding SIR, the only measures for consideration in an optimization analysis would have been the window tinting, building air sealing, the mechanical system change-out, the lighting retrofit, and the replacement of the washer and dryer (assuming a small lease cost savings). The attic insulation measure would have been a much stronger contender if the building design had allowed this measure to be implemented as expected, which would have been the case if the water heater installation had not required fuel conversion and new plumbing lines. 


\section{Conclusions}

Overall, the Beacon House retrofit successfully addressed energy use, comfort, and durability and met the general goals of the residents, staff, and funding agency. The utility data-backed, weather-normalized True-Up model clearly provided researchers a better baseline to project energy savings for this retrofit than the initial model created with software defaults for a residential building. The regression model using monthly HDD and CDD to suggest monthly energy use had the building been subjected to TMY3 weather provided strong, predictive values. This allowed researchers to disaggregate heating and cooling loads from base loads, a powerful piece of the true-up simulation effort. However, this true-up method was unable to disaggregate $71 \%$ of electricity end uses.

Obstacles were presented in evaluating energy use in a building with these architectural and operational characteristics. Energy cost savings projections were hampered by imperfect knowledge of the pre-retrofit condition. As presented in Section 4.1, understating the energy efficiencies for baseline model components produced overestimates in the energy cost savings for related measures. Savings projections for some measures were overstated because the knowledge about the building was limited due to the limited pre-retrofit audit. The attic insulation and the mechanical distribution system were affected by this. Energy cost savings projections were weakened by unknown pre-retrofit duct leakage and whole-building airtightness, as highlighted in Sections 2.2 and 2.3.

Difficulties were presented in retrofitting a transitional housing building with these architectural characteristics and of this vintage. Some age-related and architectural obstacles created unforeseen costs and effectively limited some measures. The building displayed signs of multiple renovations performed over the years that limited access to some areas of the building. Termite damage led to structural degradation of the building. Therefore, it was necessary to add wood for structural stability. These realities impacted the mechanical system replacement, limited the attic insulation measure, and ruled out a potential window retrofit and a mechanical ventilation strategy, as discussed in Sections 4.4, 4.1, and 3.4, respectively.

The kitchen presented another difficulty. The contractor thought the overall retrofit would have been more effective had the comfort in that room been addressed. Although creating an air barrier between the kitchen and the rest of the building was a logical design because of the large exhaust draws ingrained in a commercial kitchen, a preferable solution would have included independently conditioning the space with a ductless mini-split. The kitchen would still experience some energy loss through the exhaust vents regardless of where the space conditioning came from, however. Budgetary constraints meant that it was not technically possible to create adequate living space comfort in the kitchen. Further, workers did not seem bothered by the warm working environment.

Overall, the projected energy cost savings expected from the Beacon House retrofit are nearly $35 \%$; annual savings are projected to be $\$ 5,375$. A simple payback is eight years. Though the retrofit did not precisely follow the proposed package, the overall savings project roughly matches the initial pre-retrofit projections of $37 \%$ reduction in energy costs for $\$ 5,775$ annual savings with an eight-year payback. In terms of measures that provide the best projected energy cost savings and SIRs for this facility (see Section 5.1), the expected savings from the 
mechanical system upgrade, $16.3 \%$, represents almost half the entire project savings projected. Other noteworthy measures are the lighting retrofit, installation of tankless gas water heaters, and improved whole-building airtightness, which are projected to save $8.6 \%, 5.6 \%$, and $4.8 \%$ respectively. Considering the full costs involved with each measure, the best measures to consider are the lighting retrofit and the window film measure with SIRs of 2.95 and 2.08, respectively. However, when examining incremental costs where appropriate, the mechanical system upgrade provides the best economics with an SIR of 5.93.

Not surprisingly, the project considers the removal and replacement of the heating and cooling systems to be the most successful measure. In addition to the improved mechanical efficiency, the building now has balanced airflow. Removing the window units also provided opportunities for restricting uncontrolled airflow into and out of the building.

The next logical step would be to confirm energy cost savings. Researchers anticipate actual savings to be greatly influenced by the fluctuation between pre- and post-retrofit occupancy behavior, but not necessarily because the rapid turnover in residents means the pool of postretrofit occupants will be composed substantially of different people, because with 30 residents, perhaps this variation would average out. In the post-retrofit condition, staff has greater control over operational settings. However, observations show that even with greater staff control, postretrofit energy consumption may be influenced by the take-back effect. Granted additional funding, additional research to address these questions could include monitoring indoor air temperature and relative humidity, recording set points, and surveying occupants. 


\section{References}

Brozyna, K. (2012). Results from Development of Model Specifications for Multifamily Energy Retrofits. NREL/SR-5500-53624. Work performed by Integrated Building and Construction Solutions (IBACOS), Pittsburg, PA. Golden, CO: National Renewable Energy Laboratory. Accessed 2012: http://www.nrel.gov/docs/fy12osti/53624.pdf

Florida Solar Energy Center. (1996-2005). EGUSA. Accessed 2012:

http://www.energygauge.com/usares/.

"Industry Statistics Sampler: NAICS 624221 Temporary Shelters." U.S. Census Bureau, 2002. Accessed 2012: http:/www.census.gov/econ/industry/hist/h624221.htm

McIlvaine, J.; Sutherland, K.; Schleith, K.; Chandra, S. (2010). "Exploring Cost-Effective, High Performance Residential Retrofits for Affordable Housing in the Hot Humid Climate." Seventeenth Symposium on Improving Building Systems in Hot and Humid Climates; August 24-26, 2010, Austin, TX.

"Residential Finance Survey 2001: Census 2000 Special Reports.” U.S. Census Bureau, 2005: Accessed 2012: http://www.census.gov/housing/rfs/data/censr-27.pdf

RESNET. (2012). Mortgage Industry National Home Energy Rating Systems Standards, Section 303.3.3 Economic Cost Effectiveness. Oceanside, CA: Residential Energy Services Network. Accessed 2012: http://www.resnet.us/standards/mortgage 


\section{Appendix: SIR Calculation Assumptions}

\begin{tabular}{|c|r|}
\hline Economic Parameters & Values \\
\hline General Inflation Rate & $2.39 \%$ \\
\hline Discount Rate & $4.39 \%$ \\
\hline Mortgage Interest Rate & $6.15 \%$ \\
\hline Down Payment Rate & $10.00 \%$ \\
\hline Energy Inflation Rate & $4.42 \%$ \\
\hline Analysis Period (Years) & 30 \\
\hline Mortgage Period (Years) & 7 \\
\hline
\end{tabular}

\begin{tabular}{|c|r|}
\hline Measures & Useful Life (Years) \\
\hline Attic Insulation & 40 \\
\hline Window Tint & 15 \\
\hline Infiltration Reduction & 30 \\
\hline Heating \& Cooling System $^{1}$ & 15 \\
\hline Water Heating System $^{\text {Lighting }}$ & 12 \\
\hline Washer \& Dryer & 5 \\
\hline
\end{tabular}

${ }^{1}$ The SIR calculation for this measure includes the distribution system changes. An assumed 15-year useful life was used for all elements of this combined. 
